\title{
The ground stone assemblage of a metal workers community: An unexplored dimension of Iron Age copper production at Timna
}

\author{
Aaron Greener ${ }^{1}$, Erez Ben-Yosef ${ }^{2}$ \\ 1. W.F. Albright Institute for Archaeological Research, 26 Salah ed-Din St., P.O. Box 19096, 91190 Jerusalem, \\ Israel. Email: aaron@aiar.org \\ 2. The J. M. Alkow Department of Archaeology and ANE Cultures, Tel Aviv University, Tel Aviv, 69978, \\ Israel. Email: ebenyose@post.tau.ac.il
}

\begin{abstract}
:
The systematic archaeological study of the Timna Valley began over 50 years ago. Since then it has become a key site for understanding ancient copper production technologies in the Near East and beyond. However, the fantastic quantity of ground stone tools which are present at the Late Bronze and Early Iron Age copper smelting sites were never systematically studied. Questions regarding their origin, distribution, typologies, and especially their role within the chaîne opératoire of copper production, were seldom addressed. Although surprising, this has been the case for almost all of the excavated metal production sites around the world.

In the framework of the renewed excavations at several of the copper smelting sites at Timna, a pioneering study was conducted in which more than 1000 ground stone tools were identified and registered. These tools include, among others, grinding stones, pounders, anvils and mortars; most were manufactured of compacted sandstone and granite, exposed in several locations in the valley. In this paper we present a typology and quantitative analysis of the ground stone tools which were used by the metal workers, and offer an interpretation of how the various types of tools were employed as part of the copper production process. This provides new insights regarding the smelting process and the conditions needed for its successful outcome.
\end{abstract}

Keywords: Timna; copper production; ground stone tools; Iron Age; Arabah Valley

\section{Introduction}

Timna, located in the southern Arabah, on the western margin of the Dead Sea Rift Valley, holds the second largest copper ore deposits in the southern Levant (see Figure 1). The extensive archaeological study of the Timna Valley, which began over 50 years ago by Beno Rothenberg, has identified many copper smelting sites located mostly in the centre of the valley (see Figure 2), and has highlighted Timna as a key site for understanding ancient copper production technologies in the Near East and beyond (e.g., Rothenberg 1990; Craddock 1995; Pigott 1996).

Published by the School of History, Classics and Archaeology, University of Edinburgh ISSN: 2055-0472. URL: http://journals.ed.ac.uk/lithicstudies/

This work is licensed under a Creative Commons Attribution 2.5 UK: Scotland License. 


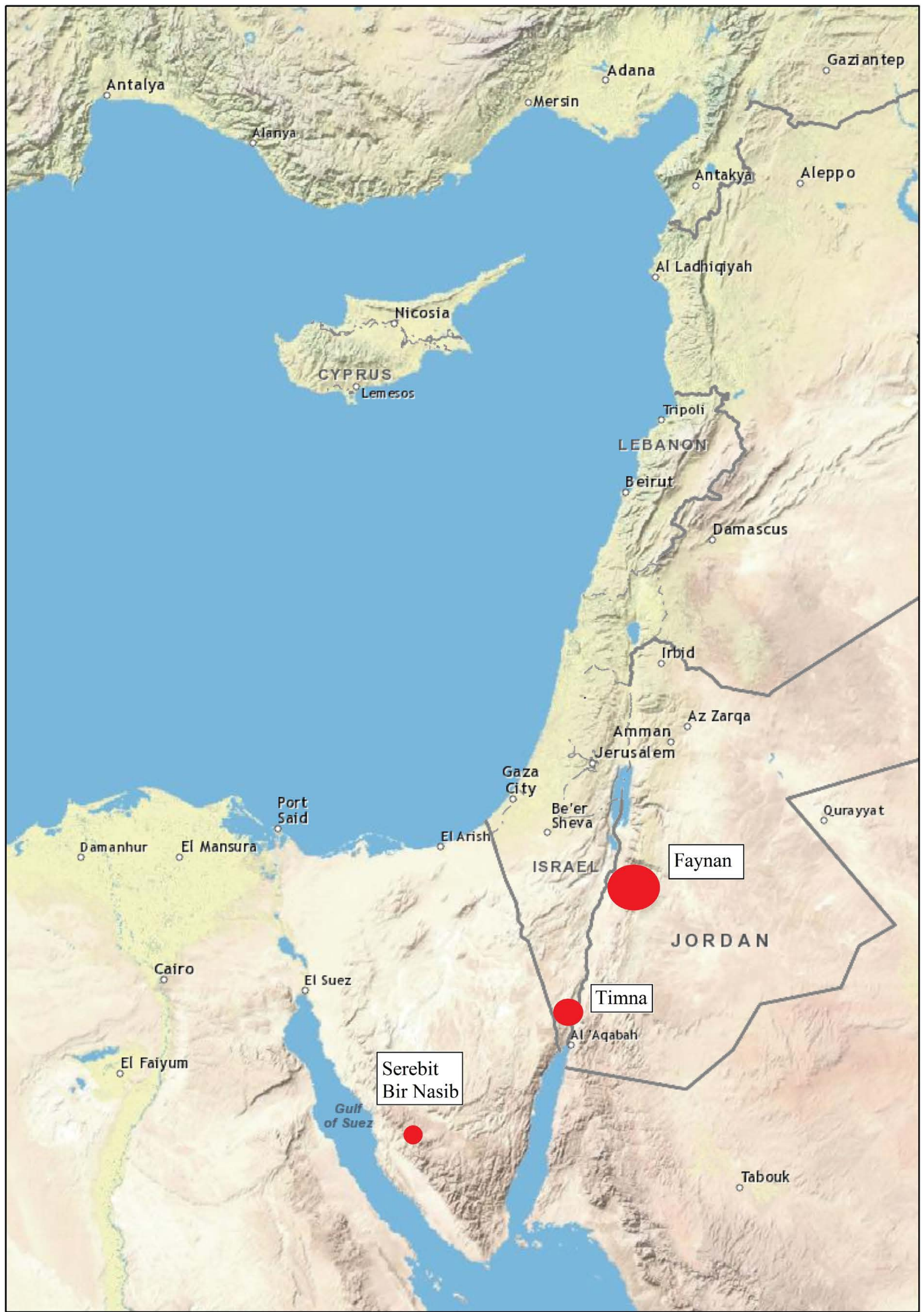

Figure 1. Map of major copper production sites in the Southern Levant; the production intensity is illustrated by the size of the red dots (this map was created using ArcGIS software by ESRI). Sources: US National Park Service, ESRI, DeLorme, MaymyIndia, OpenStreetMap contributors, and the GIS user community. 


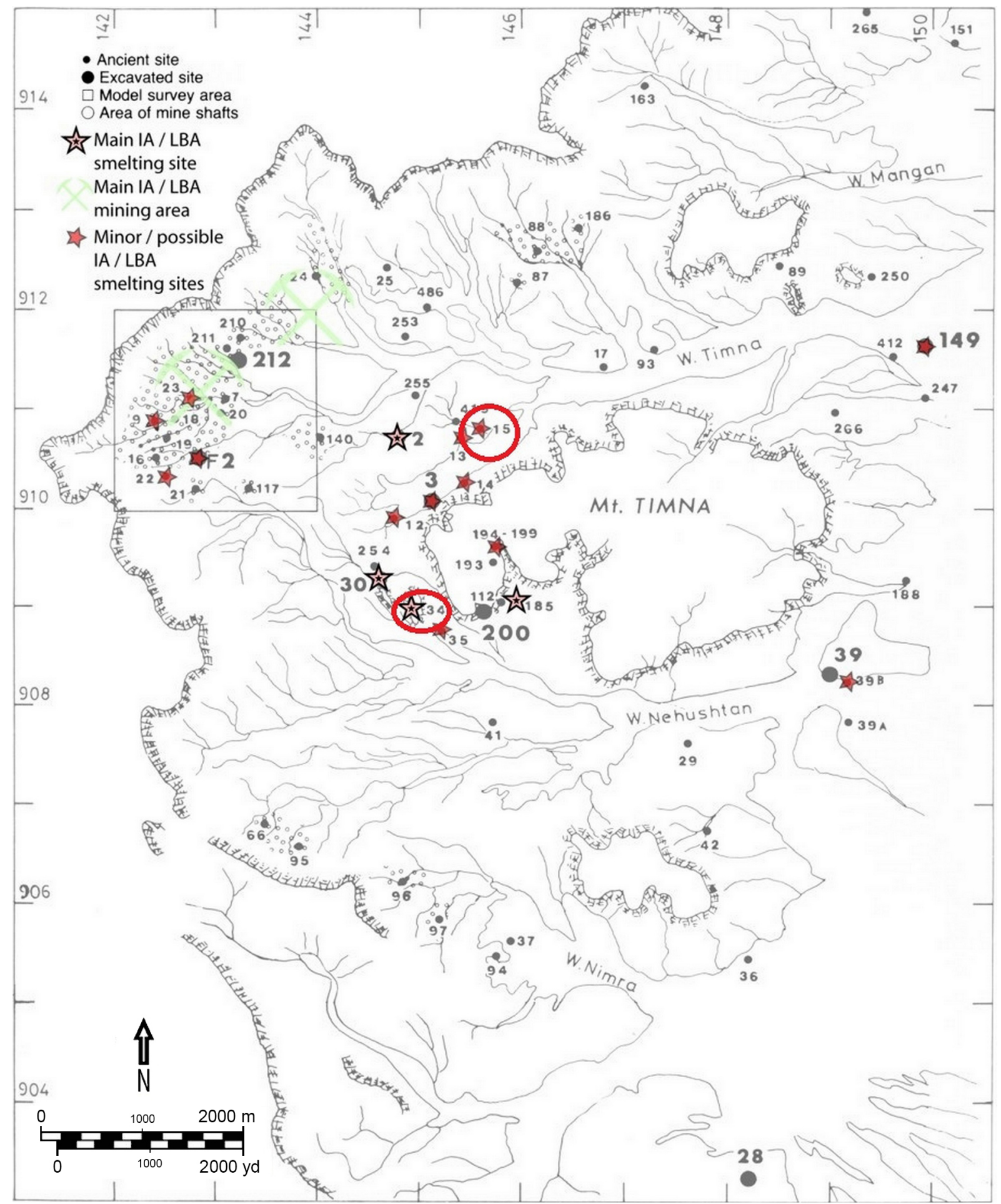

Figure 2. Late Bronze or Iron Age mining and smelting Sites in Timna Valley (after Rothenberg 1990: 2).

Although the smelting processes and related technologies at Timna and the Ancient Near East have been widely studied (e.g., Hauptmann 2007), there are still many facets of this production which remain unclear (for a detailed account of the copper production chaîne opértoire in the Iron Age Arabah Valley, see e.g., Ben-Yosef 2010; Levy et al. 2014). One of the least studied items are the ground stone tools which have been described only in a very general way, and were rarely collected (ground stone assemblages have seldom been dealt with methodically in archaeological research, even at settlement sites; e.g., Rowan \& Ebeling 2008: 1). Questions regarding their origin, distribution, typologies, and especially their role 
within the copper production process (chaîne opératoire), were surprisingly seldom addressed.

This study focuses on the large assemblage of ground stone tools found at Site 34 ("Slaves' Hill"), a large-scale industrial copper smelting site securely dated to the early Iron Age (see below). This site presents an extraordinary opportunity to study the technological aspects of this production in isolation from any domestic or other contexts. The goal of our research is to present for the first time the attributes, typology, and quantitative analysis of the ground stone tools which were used by the metal workers community, and offer an interpretation of how the various types of tools were employed during the copper smelting process. A comprehensive, detailed description of the individual Timna ground stone tools, however, must await the final publication.

\subsection{The Central Timna Valley (CTV) Expedition}

A new archaeological expedition, led by E. Ben-Yosef of the Tel Aviv University, returned to the Timna Valley in order to further investigate the copper production process, and to answer unresolved chronological, social and cultural questions. In addition to investigating several mining areas, the renewed excavations focused on smelting Site 34 (2012-2015), as well as Site 15 (2015) (see Figure 2).

Site 34 (Slaves' Hill) is an intensive copper smelting area, evident by the many large slag mounds, situated on a small hilltop to the west of Mt. Timna and enclosed by a defensive wall. This hill was left unexcavated by Rothenberg and following a detailed mapping of the hill, excavations commenced in 2013 focusing on Slag Mounds 19 and 13 and the gate area (see Figure 3). Additionally, an intensive surface survey was conducted alongside the excavations in 2014 (see Figure 4) (a similar survey was conducted at Site 15 in 2015, see below).

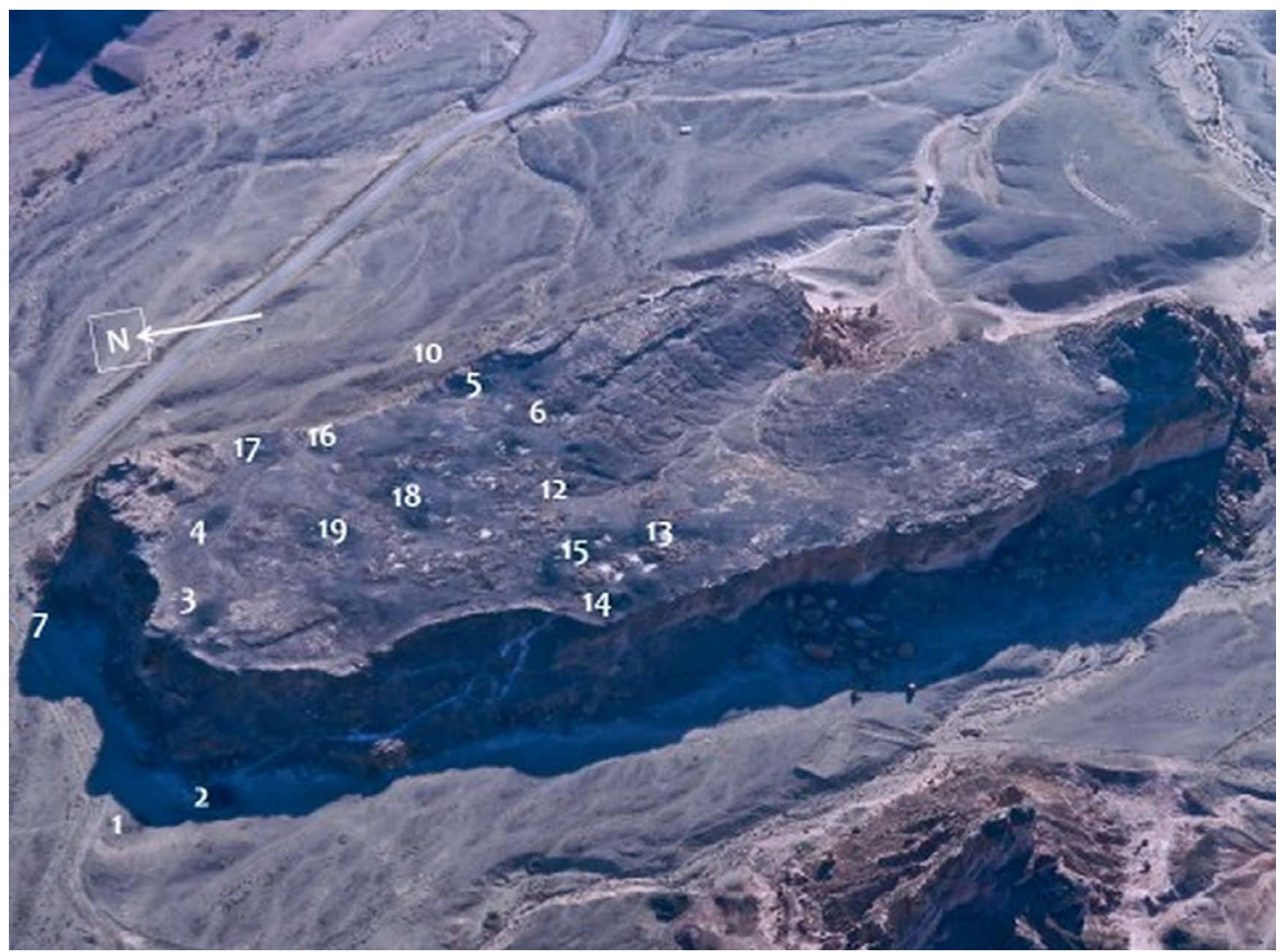

Figure 3. Major slag mounds at Site 34 (Slaves' Hill) and its surroundings; the hilltop from north to south is approximately $300 \mathrm{~m}$. 


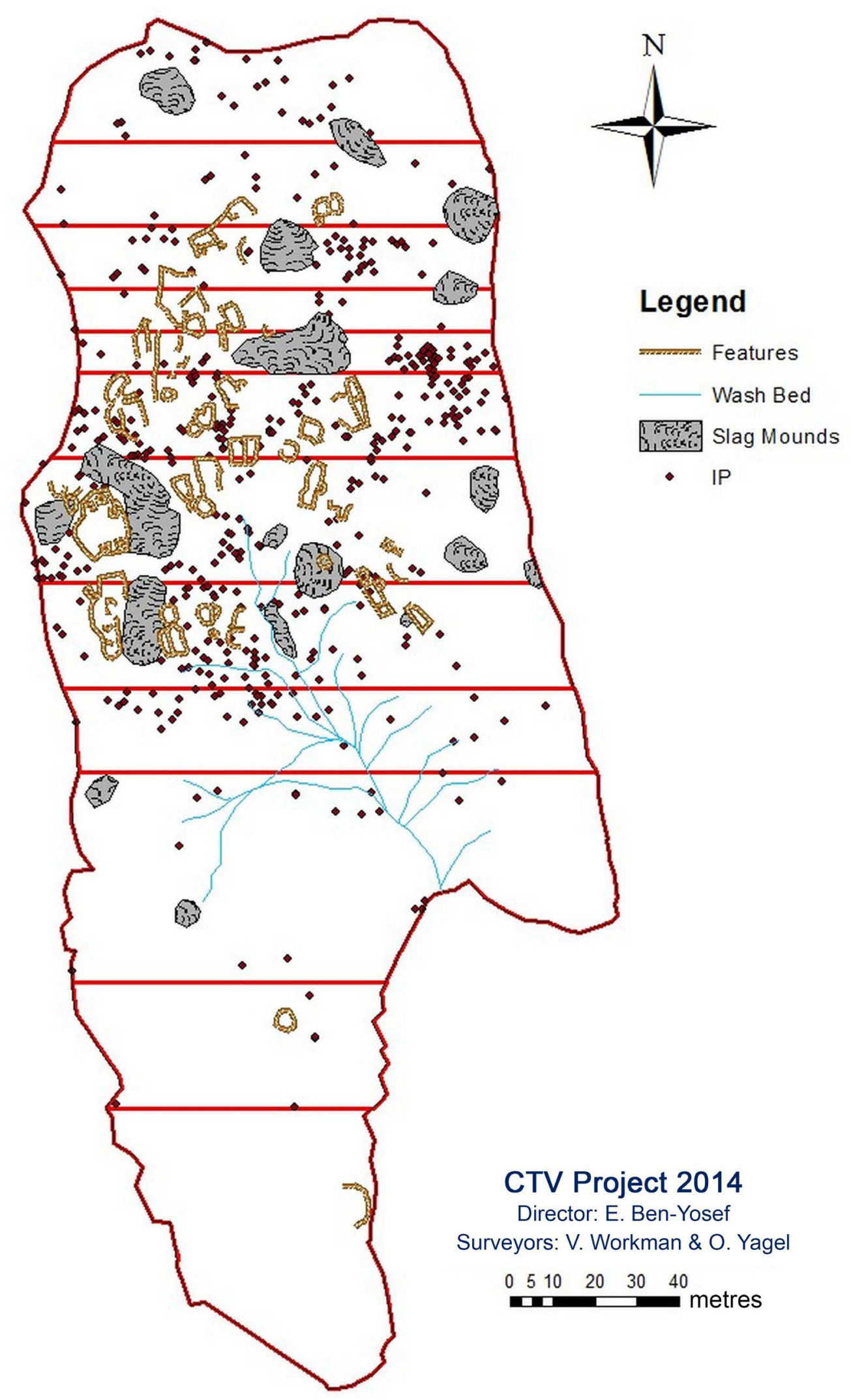

Figure 4. Site 34 survey map including bands and major architectural elements, slag mounds and location of indicative pottery (IP) Sherds (from Ben-Yosef, in press).

One of the goals of the CTV excavations was to better constrain the absolute date of copper production activity. The poor and ambiguous ceramic finds at the production sites where overshadowed by the discovery of the Egyptian shrine and other Egyptian 
paraphernalia in the valley, which were considered by Rothenberg proof that the peak of the activity took place during the Late Bronze Age, and as it was orchestrated by the Egyptians, ceased after their withdrawal from the region at the end of the Late Bronze Age (e.g., Rothenberg 1999). However, the results of several different types of tests conducted in recent years, including high resolution 14C dating from multiple slag mounds, determined that the peak of activity at Timna took place during the early Iron Age (11th-9th centuries BCE; e.g., Ben-Yosef et al. 2012). The metallurgical activity at Wadi Faynan, located ca. $100 \mathrm{~km}$. north of Timna, were dated to the same period (e.g., Levy et al. 2014), hinting at an industrial and cultural link between these two Iron Age sites.

\section{Methodological framework}

The fantastic amount of ground stone tools which were identified during the intensive surface survey conducted at Site 34 during the 2014 season, along with the tools discovered within the excavation trenches, serve as the basis for the current study. Basic information for each of the visible ground stone tools was recorded. This includes the location in which they were found, the rock type, the tool type, the size, and additional information such as the presence of dimples and cup marks. Since this assemblage of ground stone tools was logistically impossible to collect, transfer, and store (this would also be archeologically harmful to the site), only a small sample was collected for further research.

Presumably the location of the surface ground stone tools has little relation to their placement in antiquity, as many were clearly moved by recent visitors to the site, and are found in secondary contexts. Nevertheless, since this is a short-lived single-period site with no evidence of later disturbances or reuse, we can be confident that the entire assemblage is contemporaneous with the copper production evidence at the site, and should be dated to the early Iron Age. Furthermore, due to the site's topographic isolation on a hilltop surrounded by a defensive wall and cliffs, contamination with artifacts from other areas is unlikely, and the site presents an extraordinary opportunity to study the technological aspects of this production in isolation from any domestic or other contexts.

Although the surface ground stone tools, as well as most of the ones which were discovered within the excavation trenches, were found in secondary contexts, the assemblage as a whole indeed reflects the entire repertoire of ground stone applications at the site. In other words, the elusive contextual relations between the ground stone tools and the smelting installations and other architectural remains are not essential for our discussions below, which analyse the complete ground stone repertoire at Site 34 .

\section{The Iron Age ground stone assemblage}

\subsection{Tool types}

Our study focuses on the crushing and grinding tools associated with copper production, and in particular with smelting and related activities. These were manufactured from four main rock types, all originating from the nearby Mt. Timna and the wadis below the site: compacted coarse sandstone, granite, limestone, and dolomite (see Figure 5).

The types of rocks and their source were determined by surveys of the surrounding areas of the sites. The nearest outcrops of the compacted coarse sandstone and the granite are marked on the map and shown in Figures 6 and 7. 


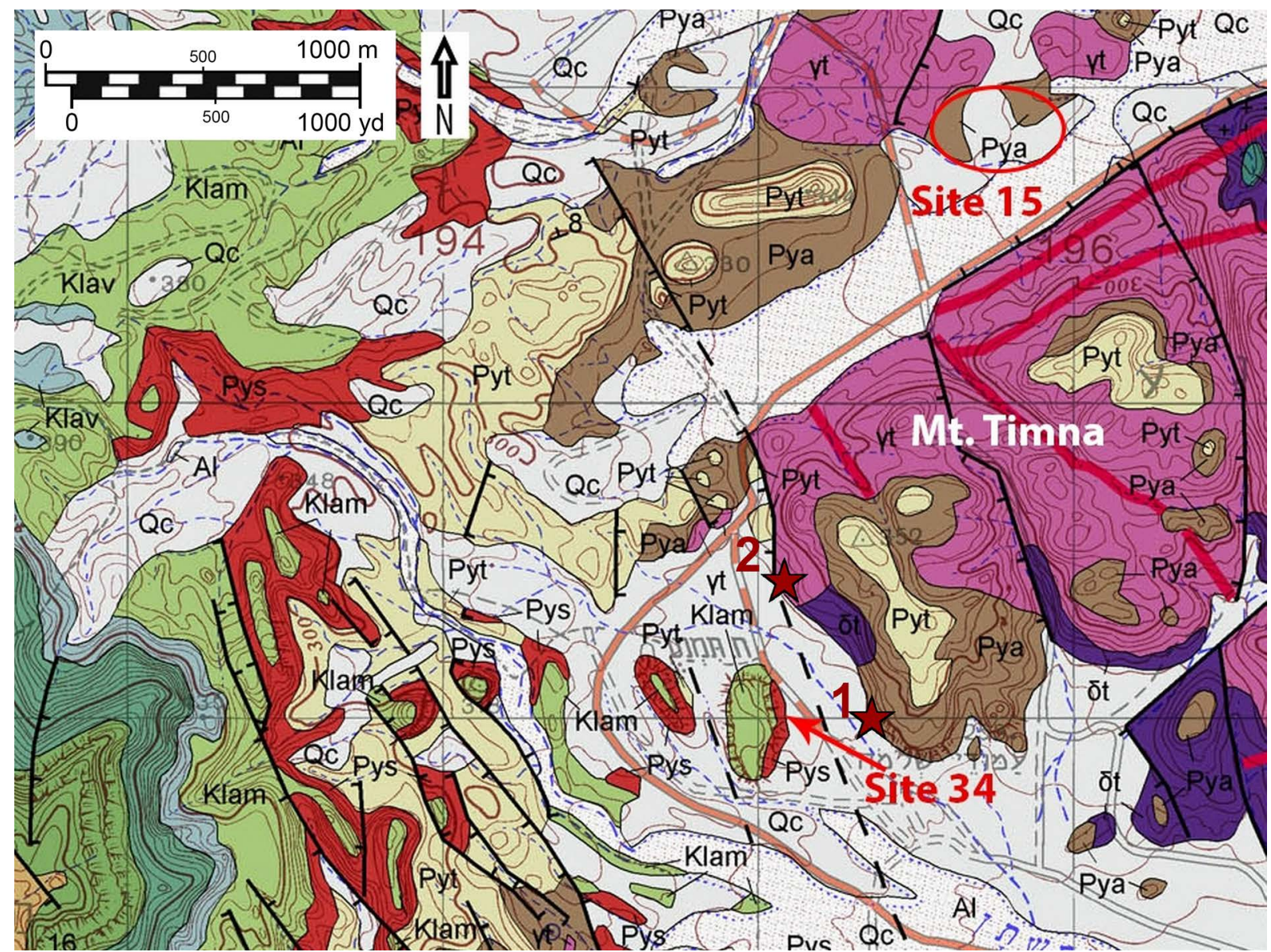

Figure 5. Timna Valley Geological Map with the location of the sites studied as part of the current research. Key for major rock types in the map: Klam (light green) = Amir Formation sandstones; Pys (red) $=$ Shehoret Formation sandstones; Pya (brown) = Amudei Shlomo Formation; Pyt (yellow) = Timna Formation (dolomite); $\Upsilon \mathrm{t}($ light purple $)=$ Alkali Granite; $\delta \mathrm{t}($ dark purple $)=$ Monzodiorite; $\mathrm{QC}=$ Stream terraces. (Adapted from the Be'er Ora Geological Map; Beyth et al. 1999).

\section{Grinding stones}

The Timna grinding stones (Figure 7) were manufactured from compacted coarse sandstone. These red rocks originate from the perimeter of Mt. Timna, and are part of the "Amudei Shlomo" geological formation. In the case of Site 34 they were probably collected from the nearby outcrop of "Amudei Shlomo" (see Figures 5 and 6). Over time and exposure to the elements, these sandstones went through a recrystallization process which turned them into quartzite-like rocks. They are relatively hard and lightweight, making these fine to medium-grained rocks well-suited for the production of grinding surfaces.

The dimples found on many of these broken stones demonstrate that they were used for pounding as well, perhaps after they broke and went out of use. It is difficult to differentiate between lower and upper grinding stones and they were thus grouped together. This problem exists also at settlement sites (e.g., Hovers 1996: 173). Most of the grinding stones are "loaf shaped" and seem to have only one working surface (unifacial); they are elongated in plan. The ones that were identified as stationary lower surfaces are elliptical or oval, and have a plano-convex or irregular base, and flat or concave work surfaces that are normally slightly convex in transverse section. Most of the elongated hand stones were used (held with either one or two hands) in a back and forth motion. The majority have flat or concave work surfaces, as a result of repeated contact with the work surfaces, and sometimes overhanging terminals, depending on the stage of wear. Most of the stones have asymmetrical transverse 
sections, which show more or less marked flattening and thinning of the "leading" edges as a result of pressure applied during forward movement. These features are also found in domestic grinding stone assemblages.

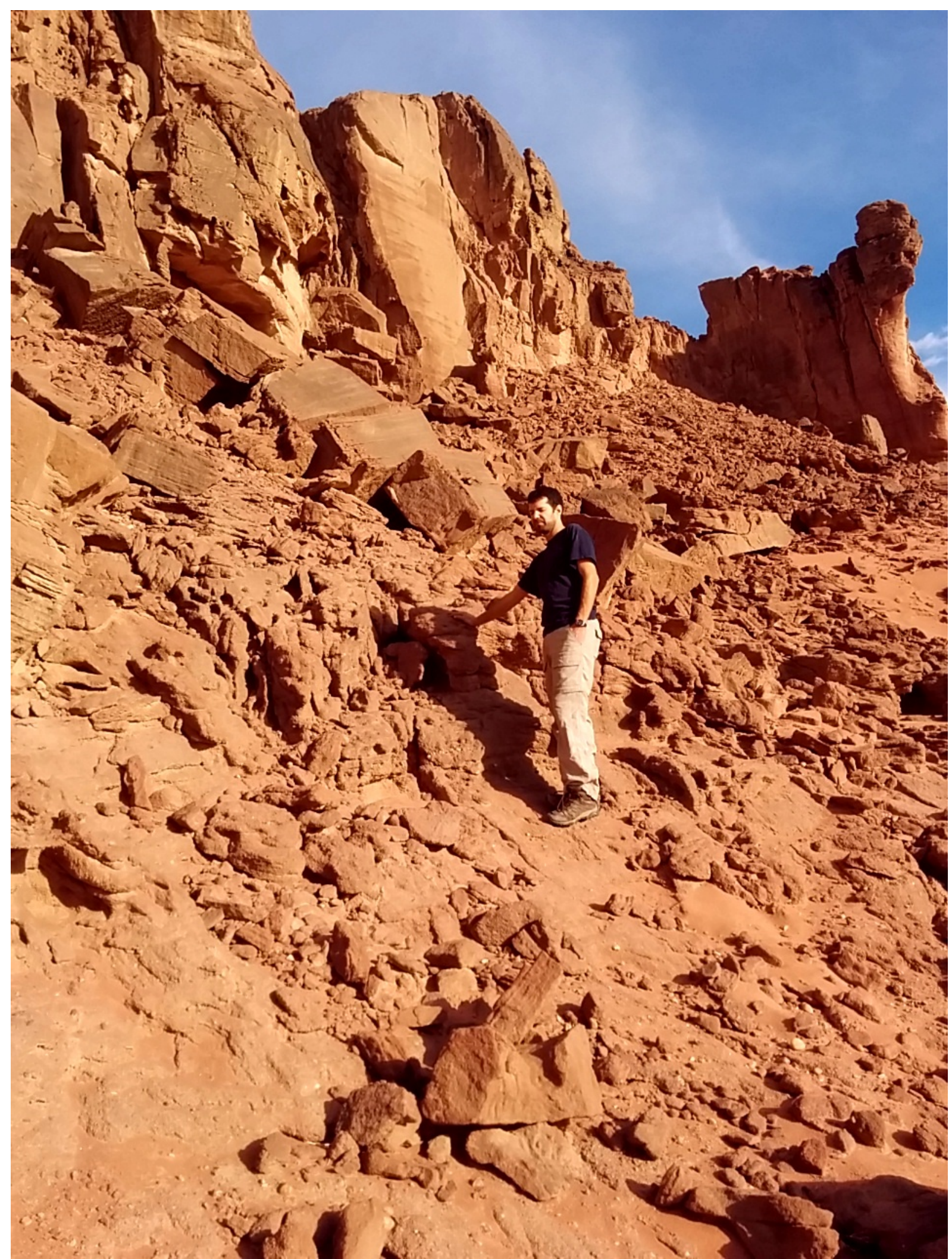

Figure 6. Compacted coarse sandstone from the Amudei Shlomo Formation found on the slopes of Mt. Timna; looking east. The photo's location is marked as \#1 in Figure 5. 

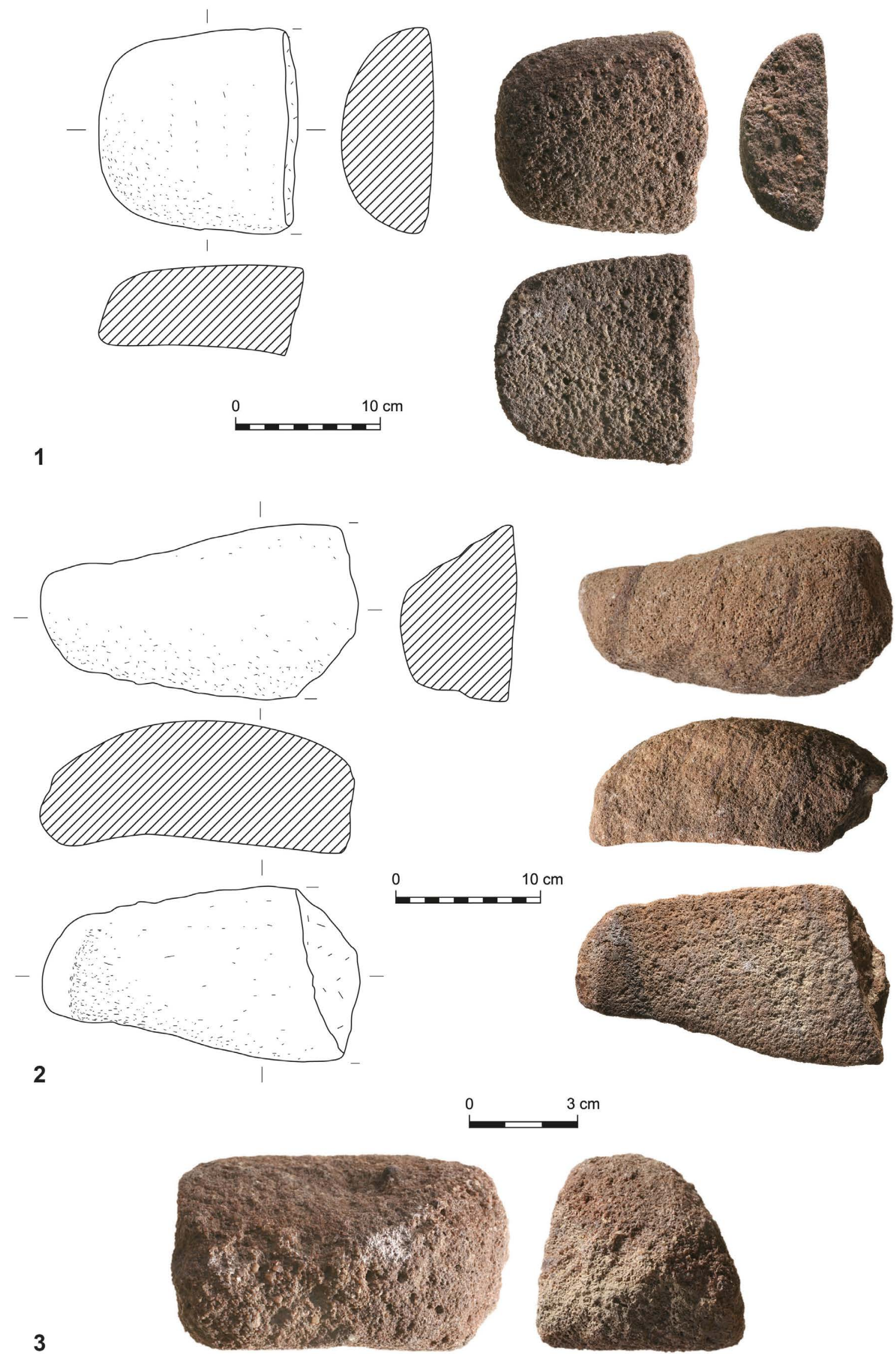

3

Figure 7. Grinding stones from Site 34. (1) B. 27 (survey): lower (?) "loaf-shaped” grinding stone; (2) B.15 (survey): upper (?) grinding stones with overhanging terminals, held with two hands; (3) B.28 (survey): upper grinding stone, held with one hand. 


\section{Pounders}

Most of the pounders were disc-shaped, and fit into the palm of the hand. They were manufactured of granite or compacted sandstones. The igneous granite rocks derive also from Mt. Timna (see Figure 8). Granite is a hard rock composed largely of quartz, mica, and alkali feldspars. The degree of compression in the internal structure of granite makes it a very strong and heavy rock. Particles are not easily detached, and thus granites remain relatively free of grit (Wright 1992: 55), making them suitable to be used for pounders (or hammerstones), mortars, and anvils. Some of the pounders are made of Cretaceous limestone found in the wadis below the site, which is slightly stronger than the compacted coarse sandstone and much heavier.

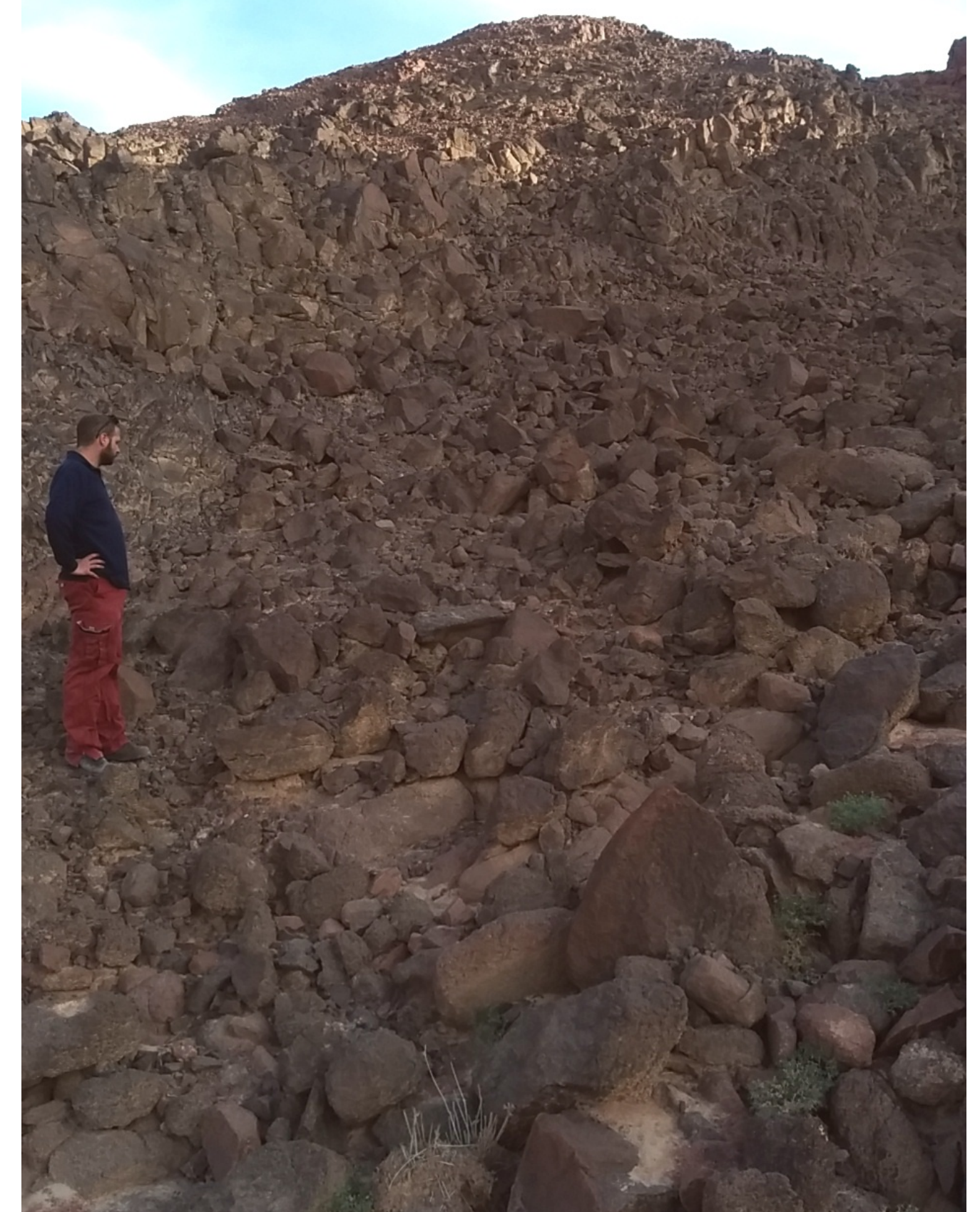

Figure 8. Granite rocks found on the slopes of Mt. Timna; looking east. The photo’s location is marked as \#2 in Figure 5. 
Most of the pounders had dimples on multiple sides which were created as a result of continuous pounding, hammering, and crushing. (See Figure 9 for examples.) They show varying degrees of intensity of use and force, ranging from light pitting and fine scratches, to chipped terminals and heavy battering and fracturing on one or multiple ends. Wright (1992: 70) wrote that forms of pounders reflect progressive reduction of a battering tool until it is no longer useful as such. There are also flint (chert) pounders which broke up in a different way. Many of the flint chips found at the site are in fact broken pieces from pounders, and not related to common flint tools production or use.
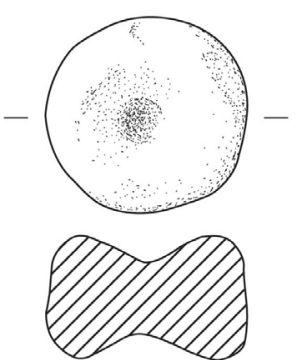

1
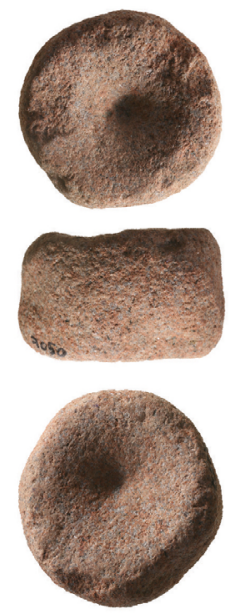

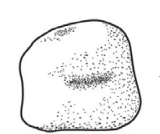

2
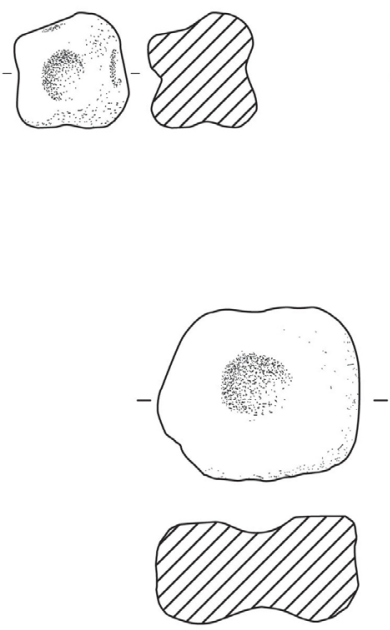

0

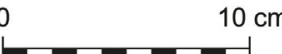

5

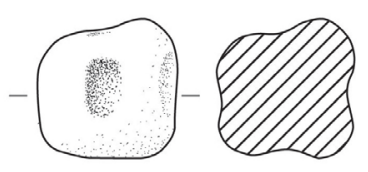

3
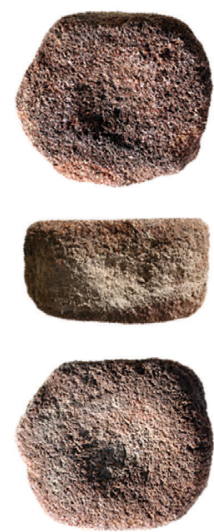

4

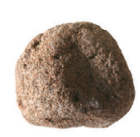

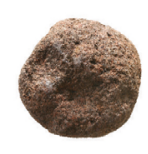

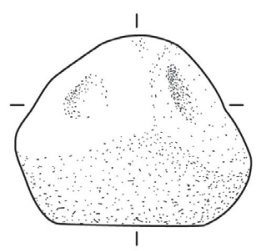

6

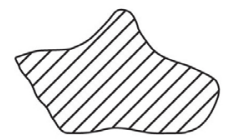

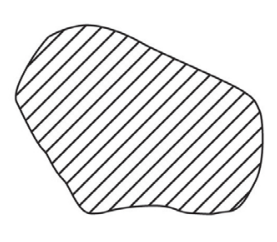
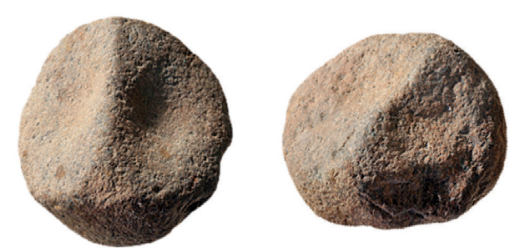

Figure 9. Pounders from Site 34. (1) B.7050 (survey): granite discoid pounder with dimples on both sides; (2) B.5432 (L.410, Area G): dolomite pounder with dimples on all sides; (3) B.7318 (survey): granite pounder with dimples on all sides; (4) B.1 (survey): granite pounder with dimples on all sides; (5) B.10 (survey): discoid compacted coarse sandstone pounder with dimples on both sides; (6) B.5818 (L.519, Area A): granite pounder with dimples on all sides.

\section{Anvils}

The anvils (Figure 10) are irregularly-shaped large rocks with multiple cup marks as a result of the above mentioned pounding action. Most of the anvils were made of granite, though some were made of dolomite of the Timna geological formation, which is a hard rock that often breaks up into layers. 

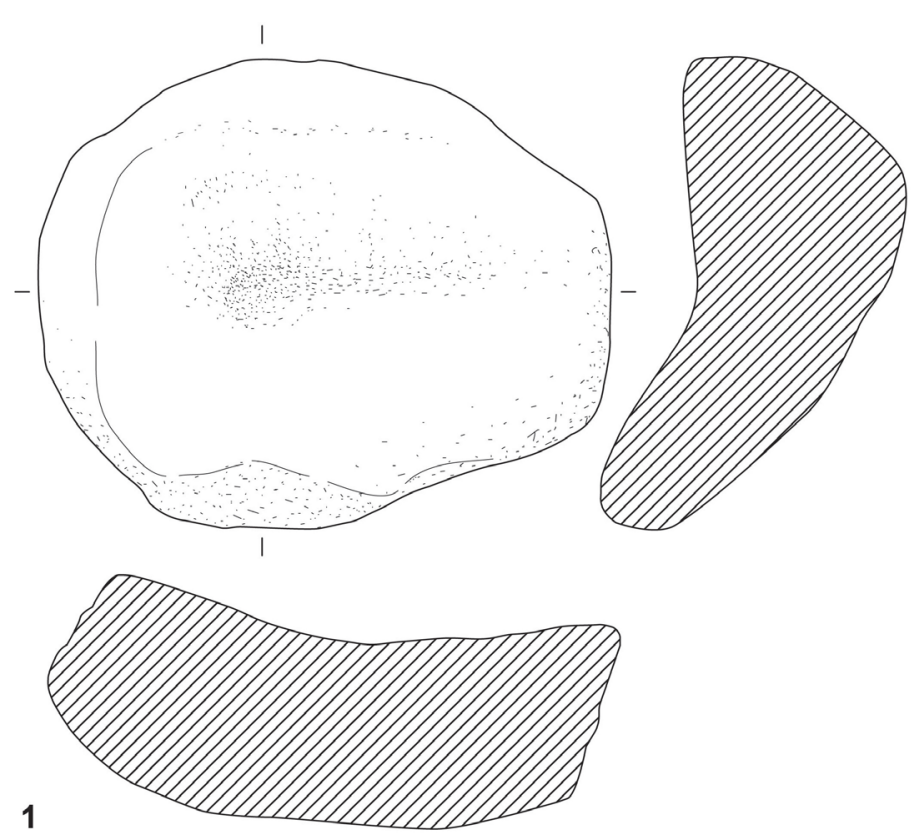
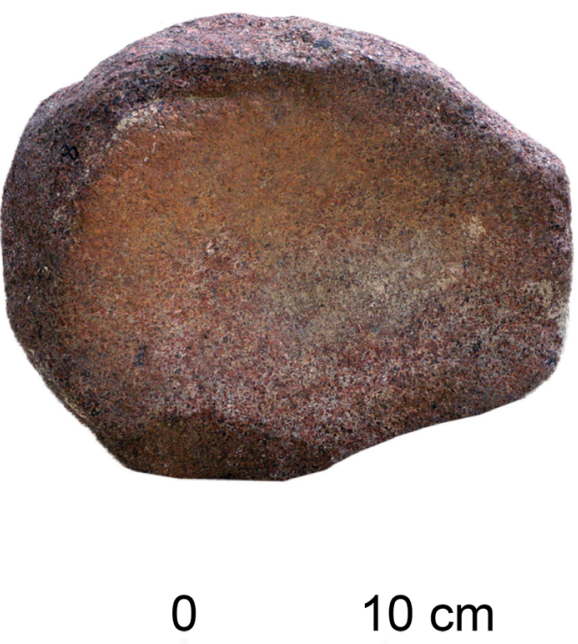
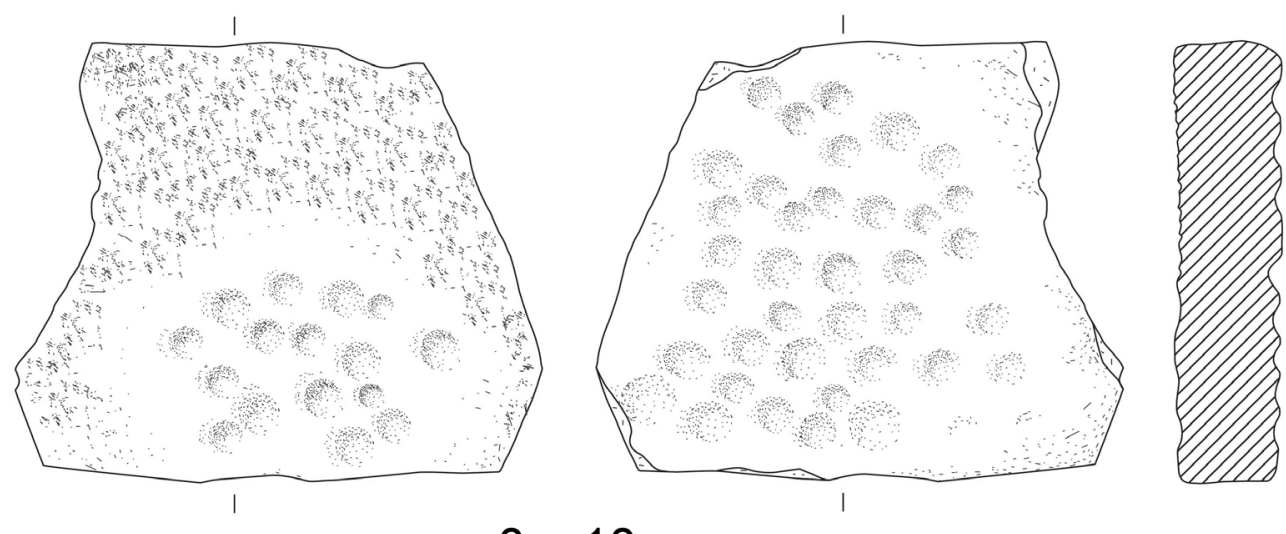

$0 \quad 10 \mathrm{~cm}$

2

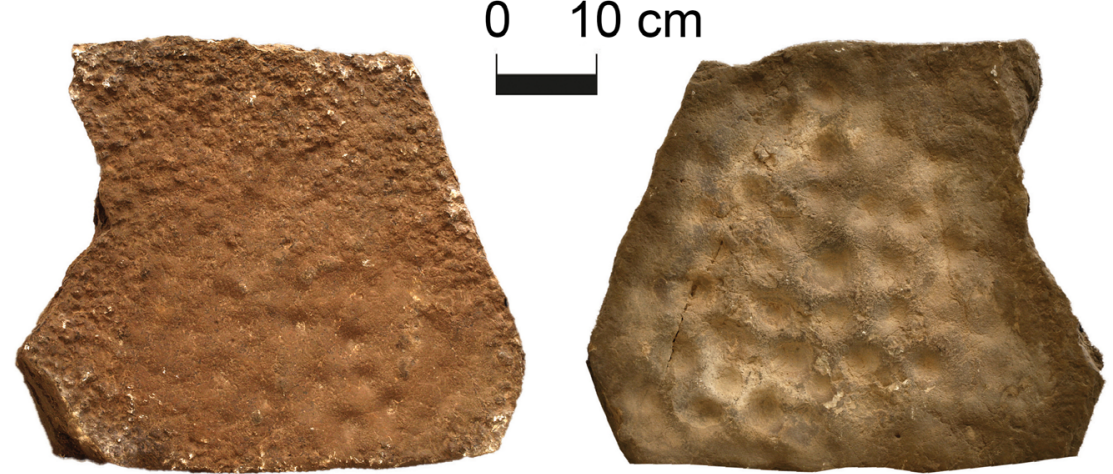

Figure 10. (1) B.8 (survey): large granite mortar boulder; (2) B.6 (survey): dolomite anvil with multiple cup marks on both sides.

\section{Mortars}

The mortars (Figures 10 and 11) are usually granite or limestone boulders with a smoothed, wide hollow. They have visible wear on one face, and the deep rounded nature of the cavity suggests grinding or pounding in a vertical, rotary motion. Many mortars were cut directly into the bedrock at Site 34. These mortars are easily identified on the eastern part of the hilltop (see Figure 12), though the fact that we found a few during the excavations demonstrates that they were widespread in other areas of the hill, and eventually covered up by the slag mounds. 

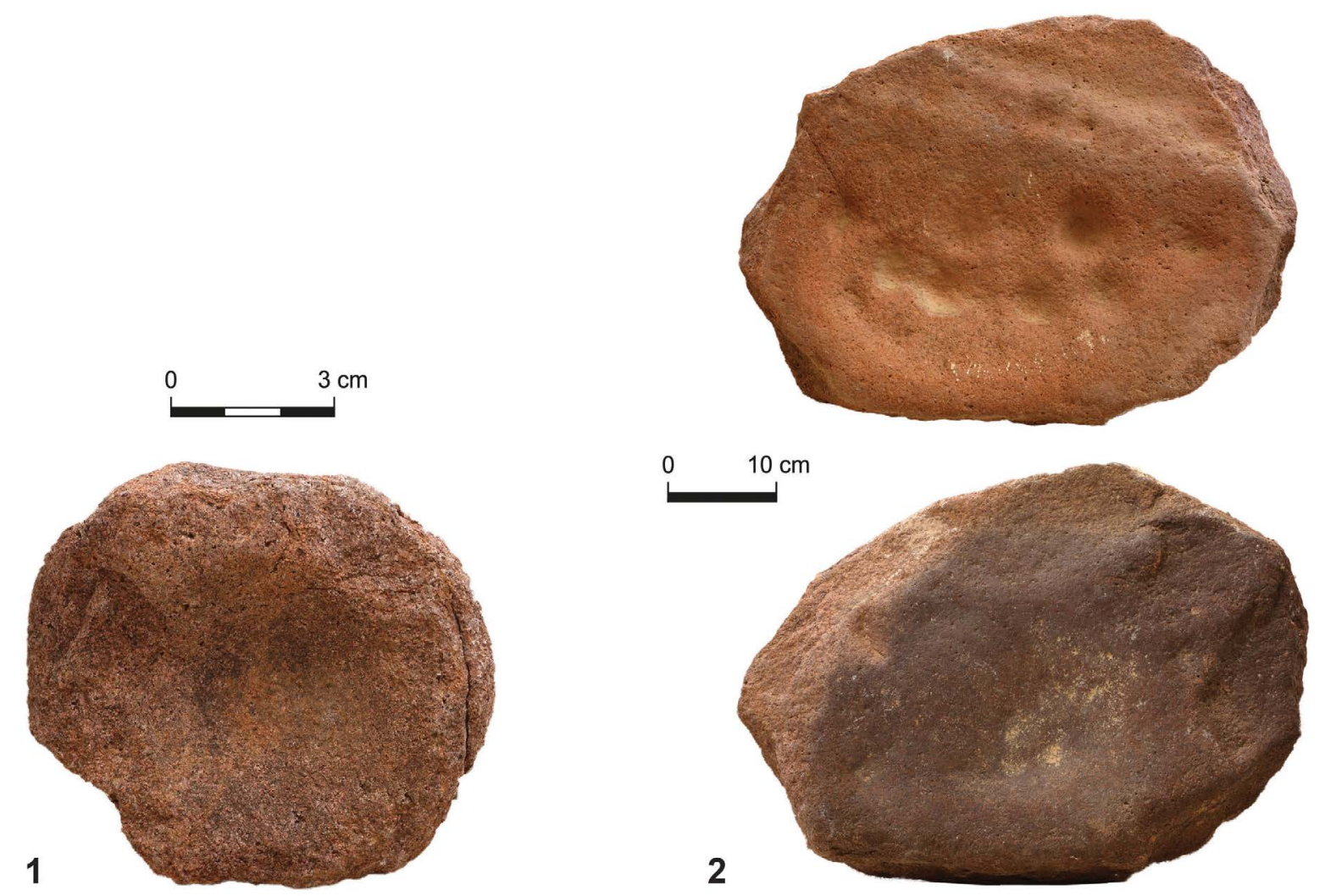

Figure 11. (1) B.35 (survey): granite mortar; (2) B.18 (survey): large granite anvil or mortar with multiple cup marks on both sides, as well as a smoothed surface.

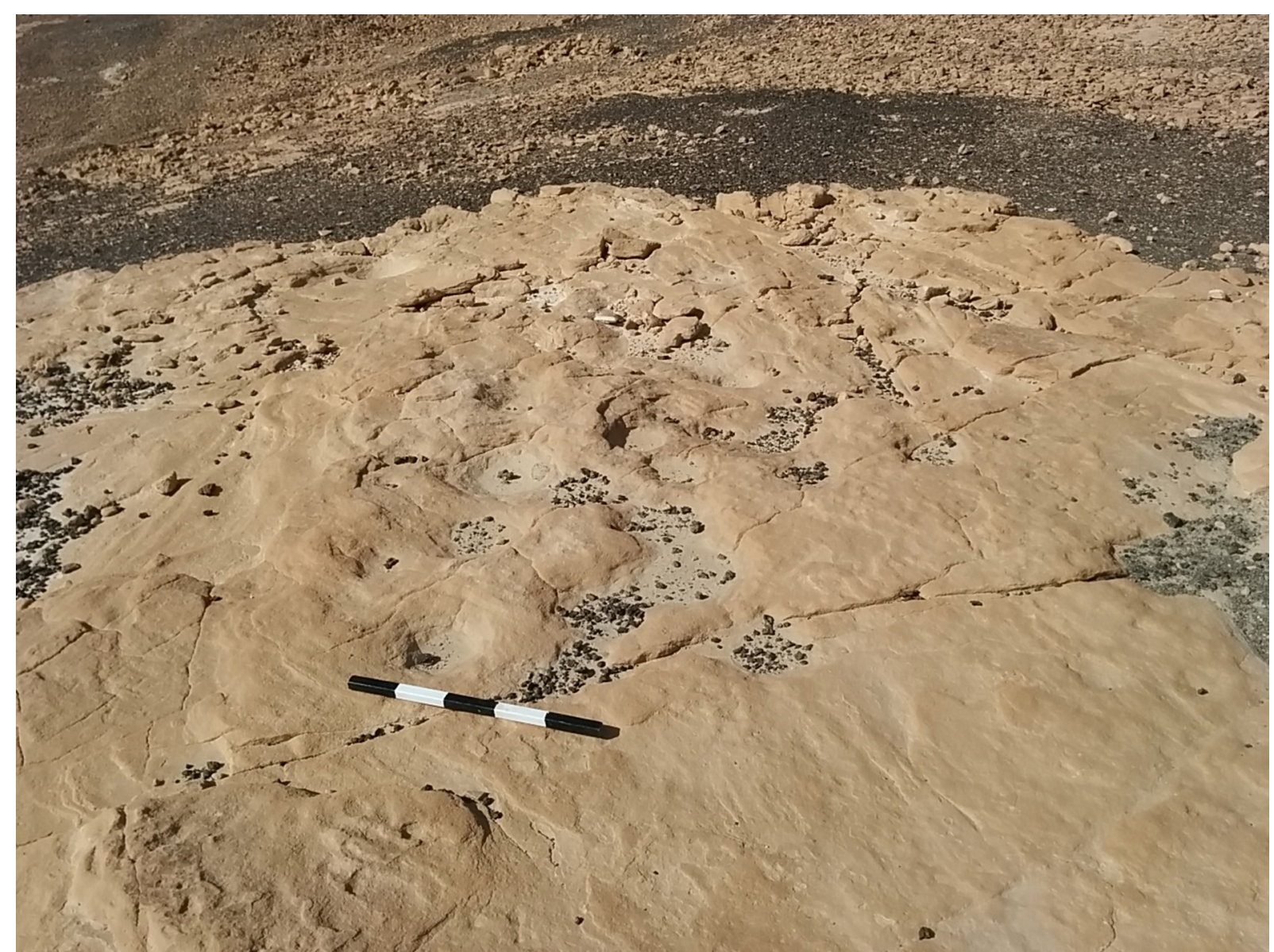

Figure 12. Bedrock mortars and cup marks on the eastern side of Site 34; looking west. 


\subsection{Distribution of ground stone tools at Site 34}

During three excavation seasons in 2013-2015 at Site 34, fifty ground stone artefacts were excavated and collected, although most are from fills of copper production waste, thus limiting their intra-site comparative contextual value. The frequencies of the rock and tool types are presented in Figures 13 to 16. Figure 13 demonstrates that about half of the tools were manufactured of the compacted coarse sandstones, and the remainder were divided mostly between granite and limestone. Additional rocks include dolomite, soft sandstone, and river stones (pebbles). Figures 14 and 15 indicates that although the quantities of grinding stones and pounders were similar at Site 34 (21-22), a closer examination of the excavation areas reveals that the grinding stones had a greater presence at the smelting areas (slag mounds 13 and 19), while pounders were more common in the gate area (area G). Other ground stone tool types include a mallet, a basin, and an unknown tool. Figure 16 demonstrates that the pounders were manufactured of different rock types, mostly granite and limestone.

In addition to the ground stone tools from the excavations, 1,171 ground stone tools were recorded during the intensive surface survey at Site 34. The distribution of the rock and tool types is presented in Figures 17 and 18. The analysis of the survey reveals a greater presence of the compacted coarse sandstones than the results of the excavations (68\% vs. 52\%). Limestone tools, mostly pounders, were not identified nearly as much in the survey (5\% vs. $18 \%$ in the excavations). Some of the limestone tools may have been missed during the survey because they did not stand out as much as the other red rock types. It is noteworthy that limestone and dolomite were used also in the architectural features at the site.

\section{Ground stones from Site $34(\mathrm{~N}=50)$}

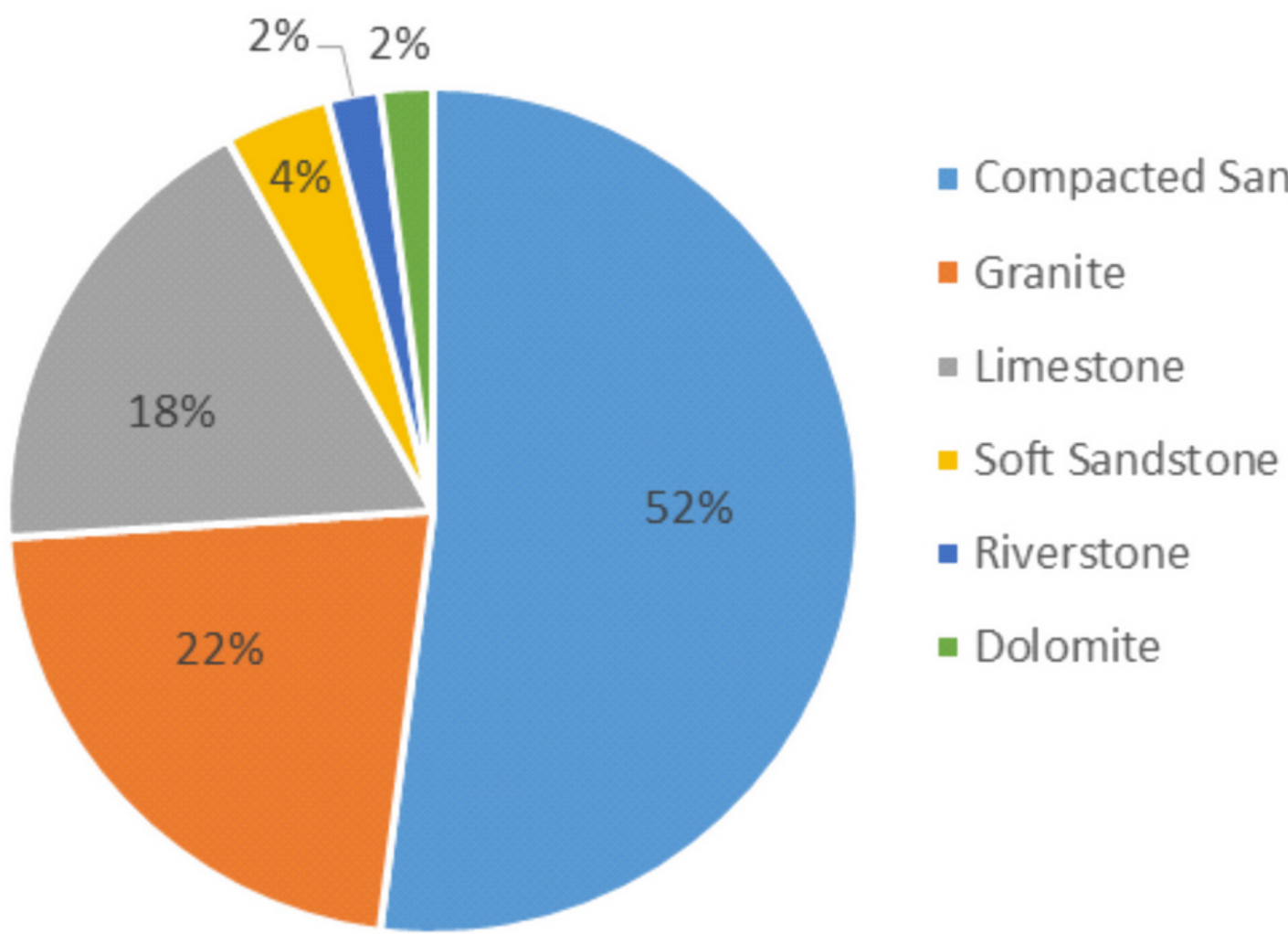

Figure 13. Distribution of ground stone rock types from Site $34(\mathrm{~N}=50)$. 


\section{Ground Stones from Site 34, Timna ( $\mathrm{N}=50)$}

\section{4}

12

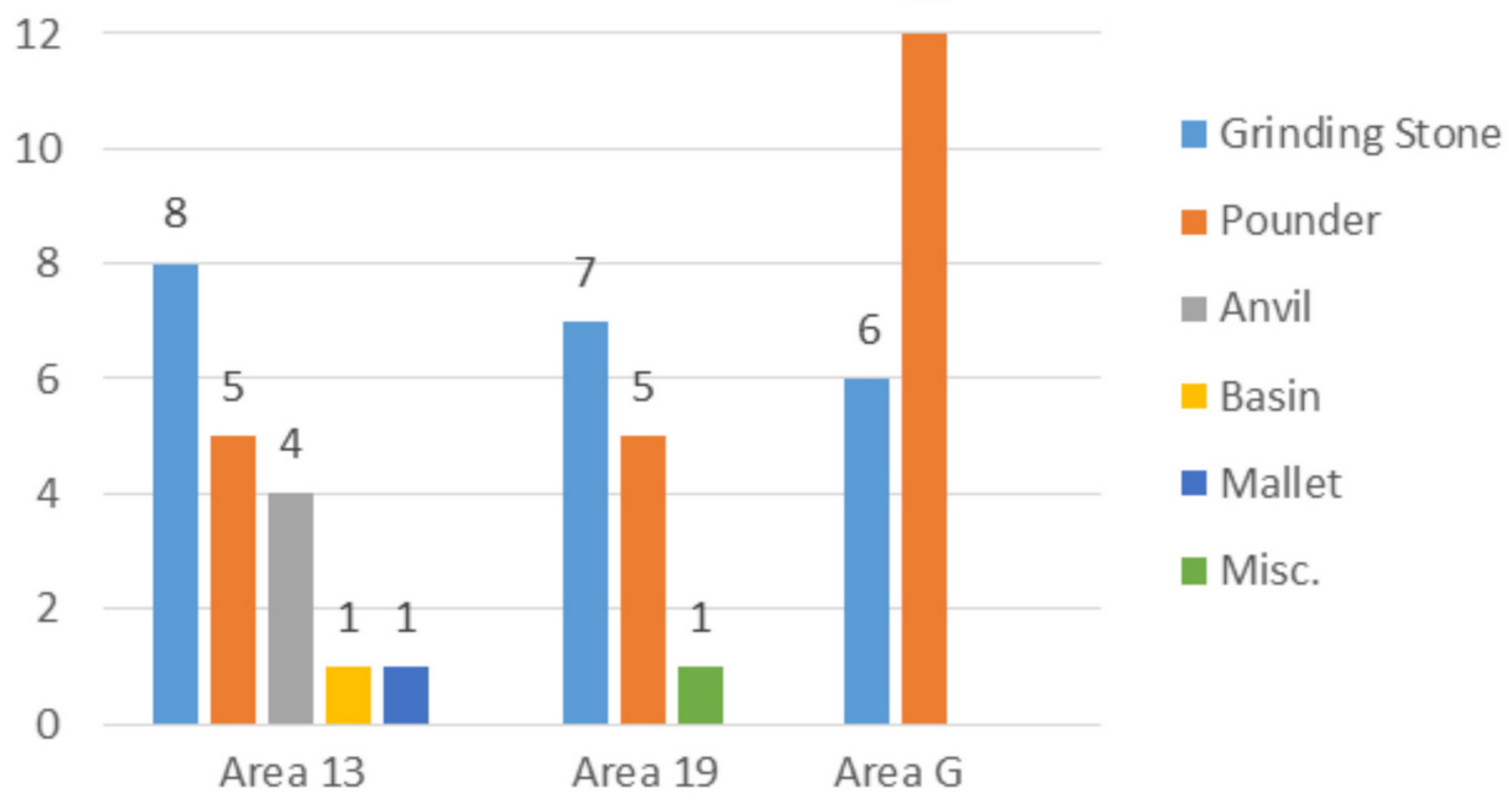

Figure 14. Distribution of ground stone tool types at Site 34.

\section{Ground Stones from the Smelting Areas at Site 34 , Timna $(\mathrm{N}=32)$}

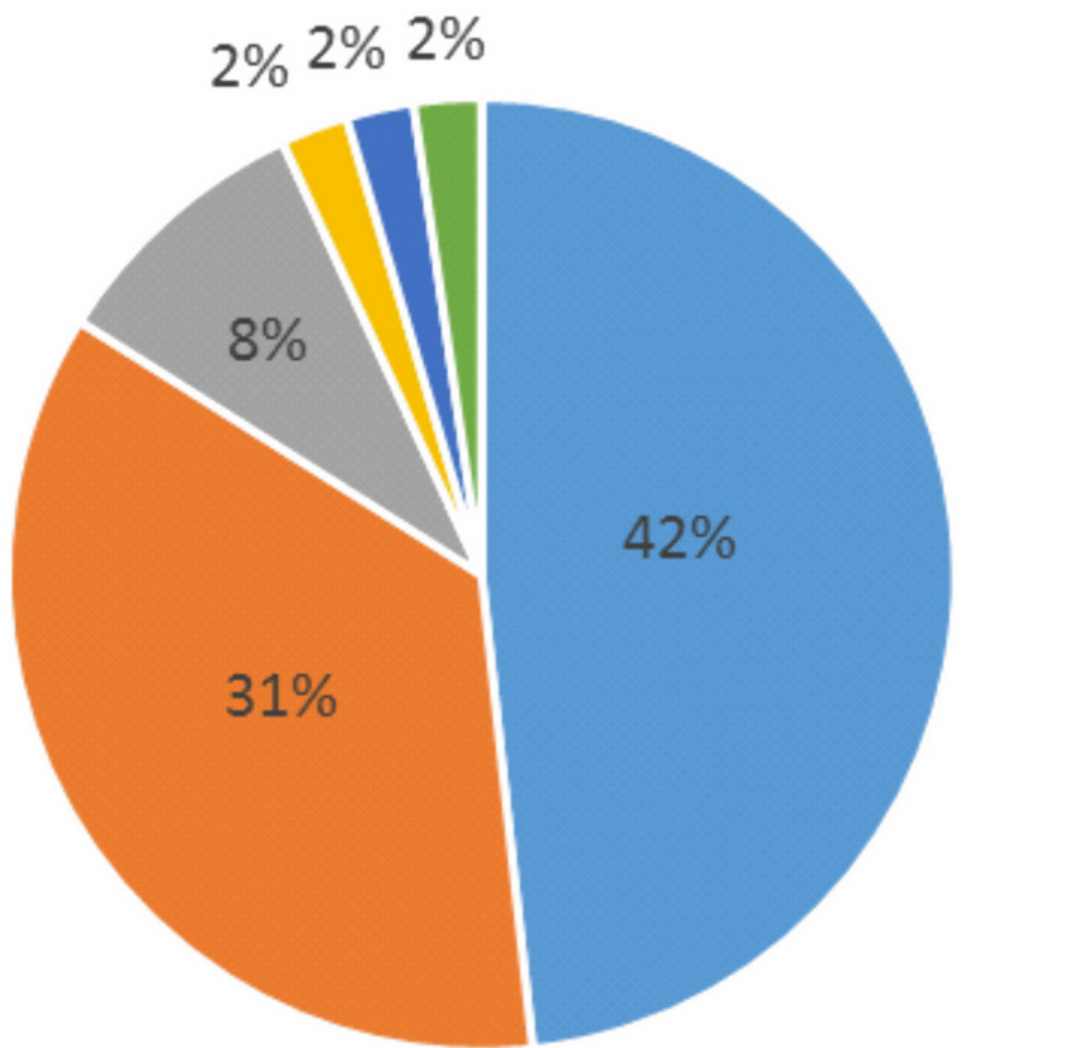

- Grinding Stone

- Pounder

- Anvil

Basin

- Mallet

- Misc.

Figure 15. Distribution of ground stone tool types at Site 34 smelting areas. 


\section{Ground Stones from Site 34, Timna $(\mathrm{N}=50)$}

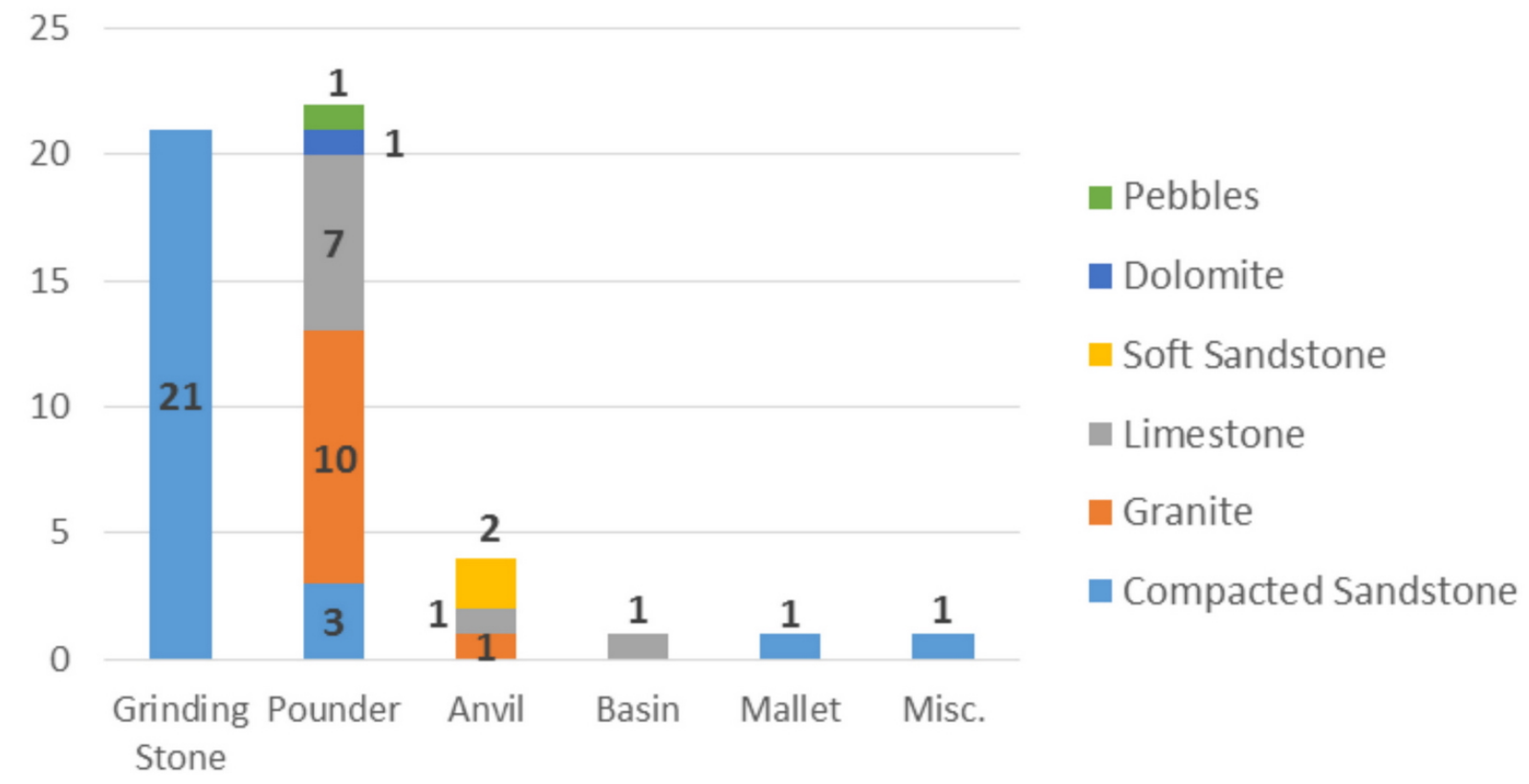

Figure 16. The rock types from which the Site 34 ground stone tools were manufactured.

\section{Ground Stones from Site 34 Survey, Timna ( $N=1171)$}

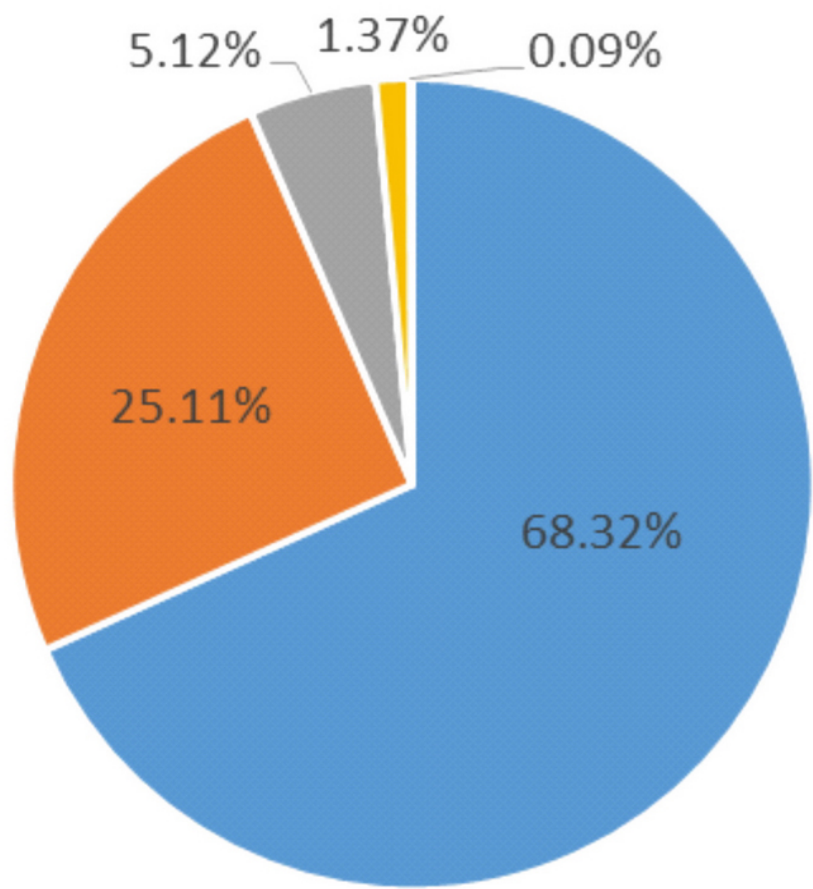

- Compacted Sandstone

- Granite

- Limestone

- Dolomite

- Soft Sandstone

Figure 17. Distribution of ground stone rock types from the Site 34 survey.

The ratios between the various ground stone tools recorded in the survey are similar to the ratios of the tools found within the excavations of the smelting areas. However, the large anvils and mortars seem to be underrepresented within the excavations. This may be explained by the fact that many of the mortars were cut directly into the sandstone bedrock and were not portable objects. Additionally, most of the pounders found in the excavations 
were made of granite and limestone, while the ones identified in the survey were manufactured of granite and compacted coarse sandstone (see Figure 19).

\section{Ground-Stones from Site 34 Survey, Timna ( $N=1159)$}

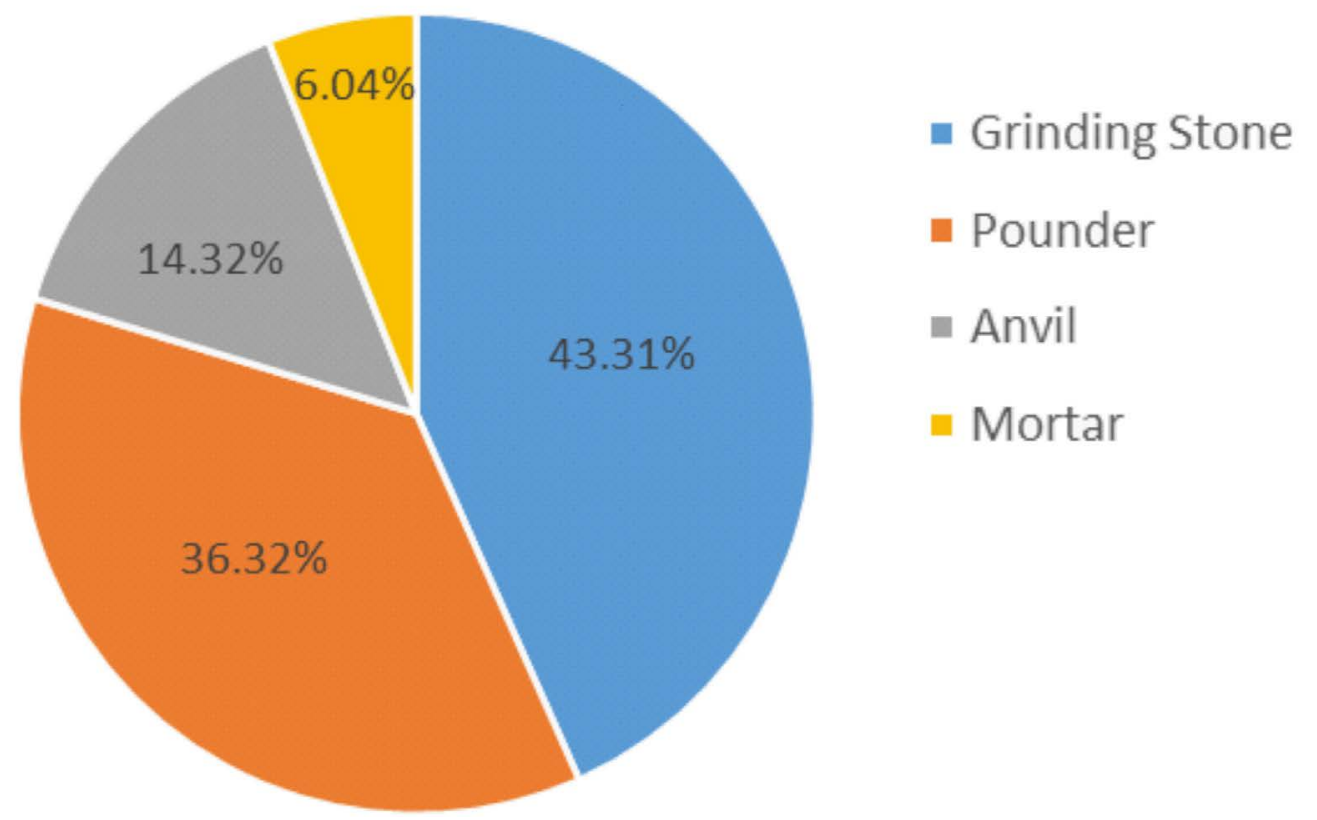

Figure 18. Rock type frequencies of ground stone from the Site 34 survey (unclassified tools not included).

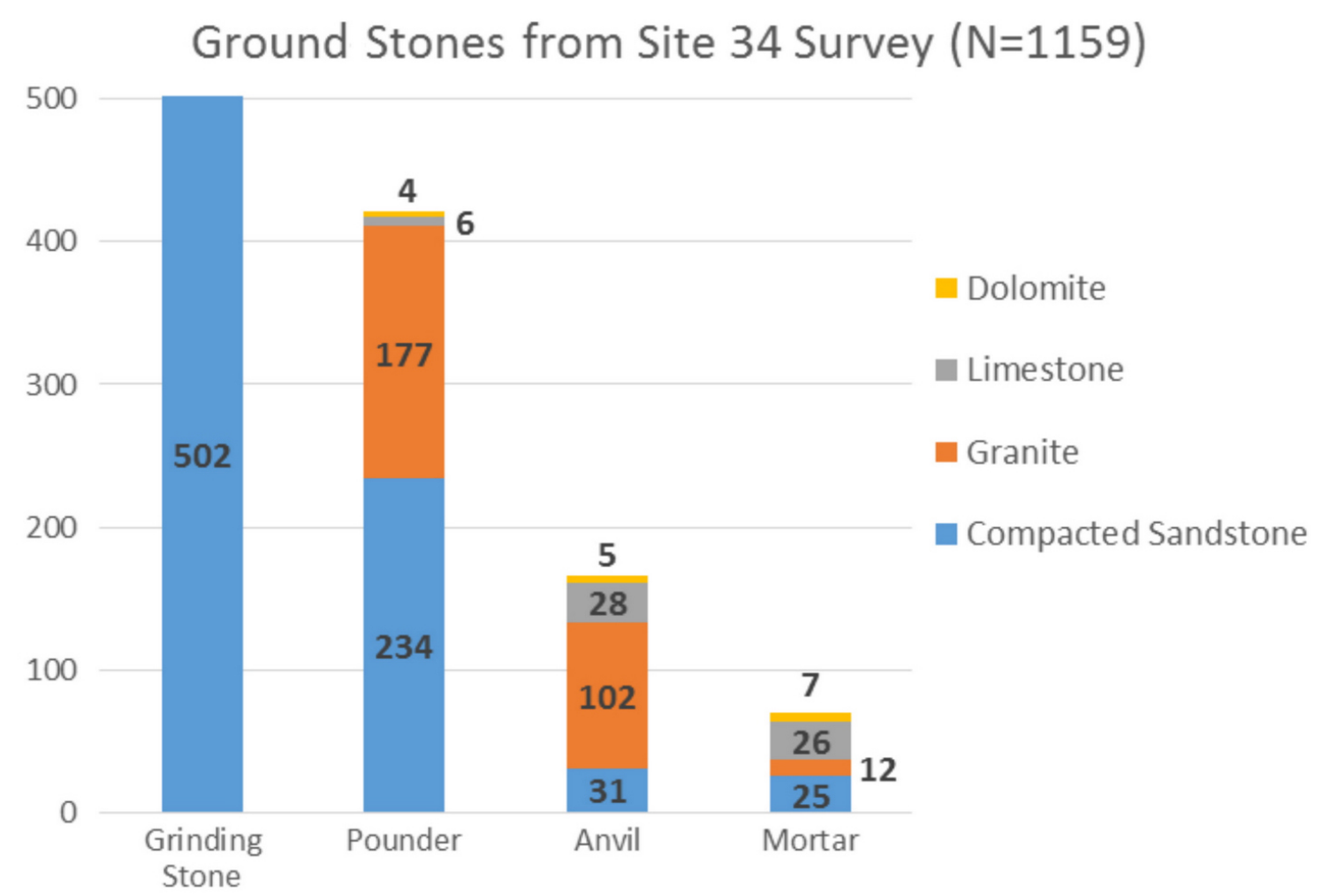

Figure 19. Rock type frequencies of ground stone assemblage found at Site 34. 


\subsection{The Site 15 ground stone assemblage}

Site 15, excavated in 2015, is a small smelting site to the north of Mt. Timna which has different features than Site 34 and the other Iron Age smelting sites. It is unprotected and located in the valley, and there are rectangular structures alongside the slag mounds (see Figure 20). These characteristics hint at the possibility that the activity there may have taken place at a different period than Site 34, probably during the end of the Late Bronze Age. The uncertain date and character of the site allows only preliminary observations about the ground stone tools found there.

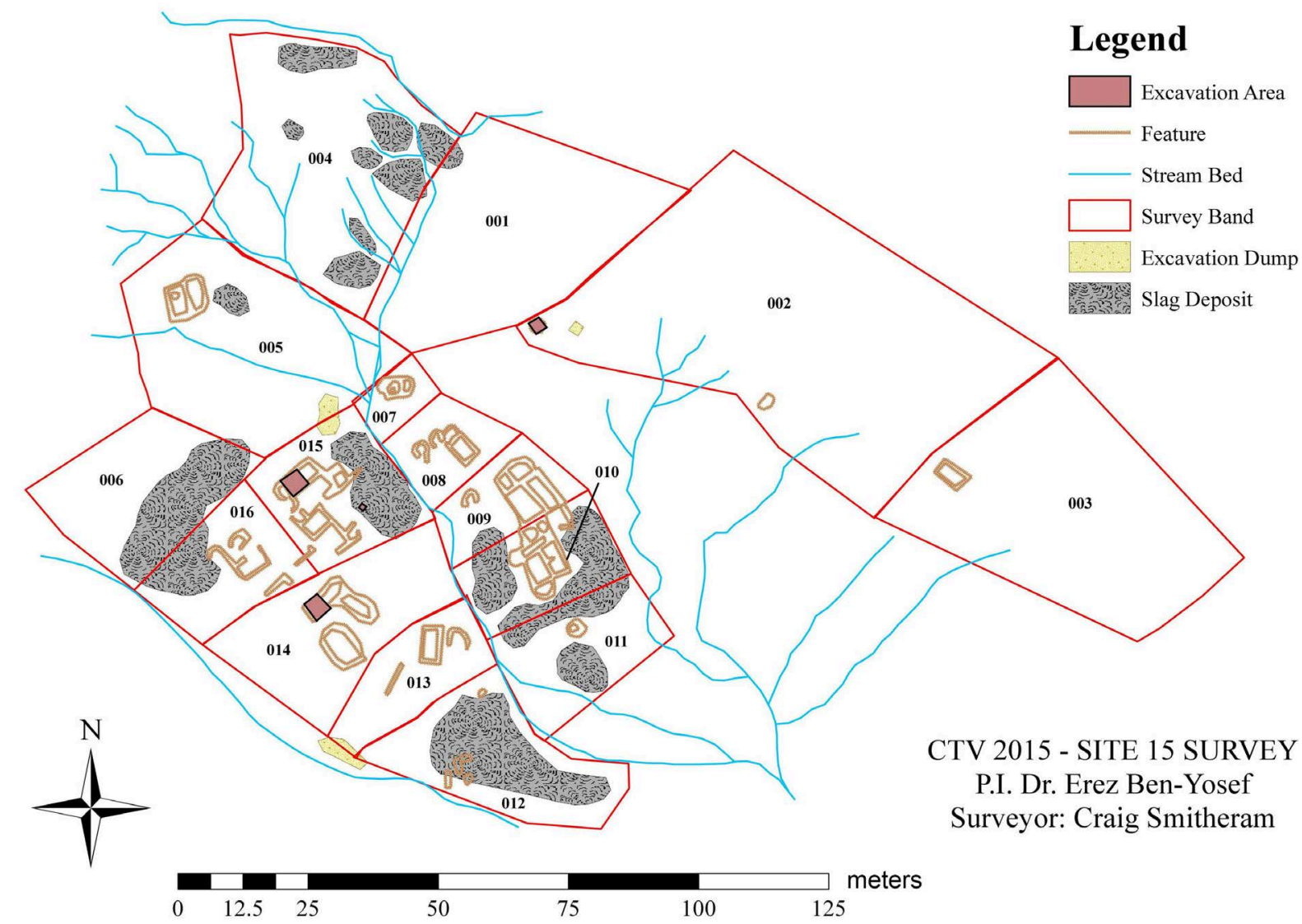

Figure 20. Site 15 survey map including bands and major architectural elements and slag mounds (from BenYosef, in press).

Twelve ground stone tools were discovered and collected during the 2015 excavation season at Site 15, and 75 were recorded in the surface survey (see Figure 21 for selected ground stone tools). The ratios between the tool types identified during the survey are similar to those which were identified in the Site 34 survey. This may indicate that they were utilized in a similar way at both Sites 34 and 15, regardless of whether both sites represent two distinct time periods or were active simultaneously. The rock types at these sites, however, are different. While most of the pounders and anvils were manufactured of granite at Site 34, the ones at Site 15 were manufactured of limestone. The reason for this difference is unclear, as granite was readily available at Site 15 and limestone was as available as granite at Site 34 . Another preliminary observation is the concentration of several polishing stones from Area C (see examples in Figure 21:2, 4), which are likely related to secondary metallurgical activity such as melting, casting, and the production of final objects. 

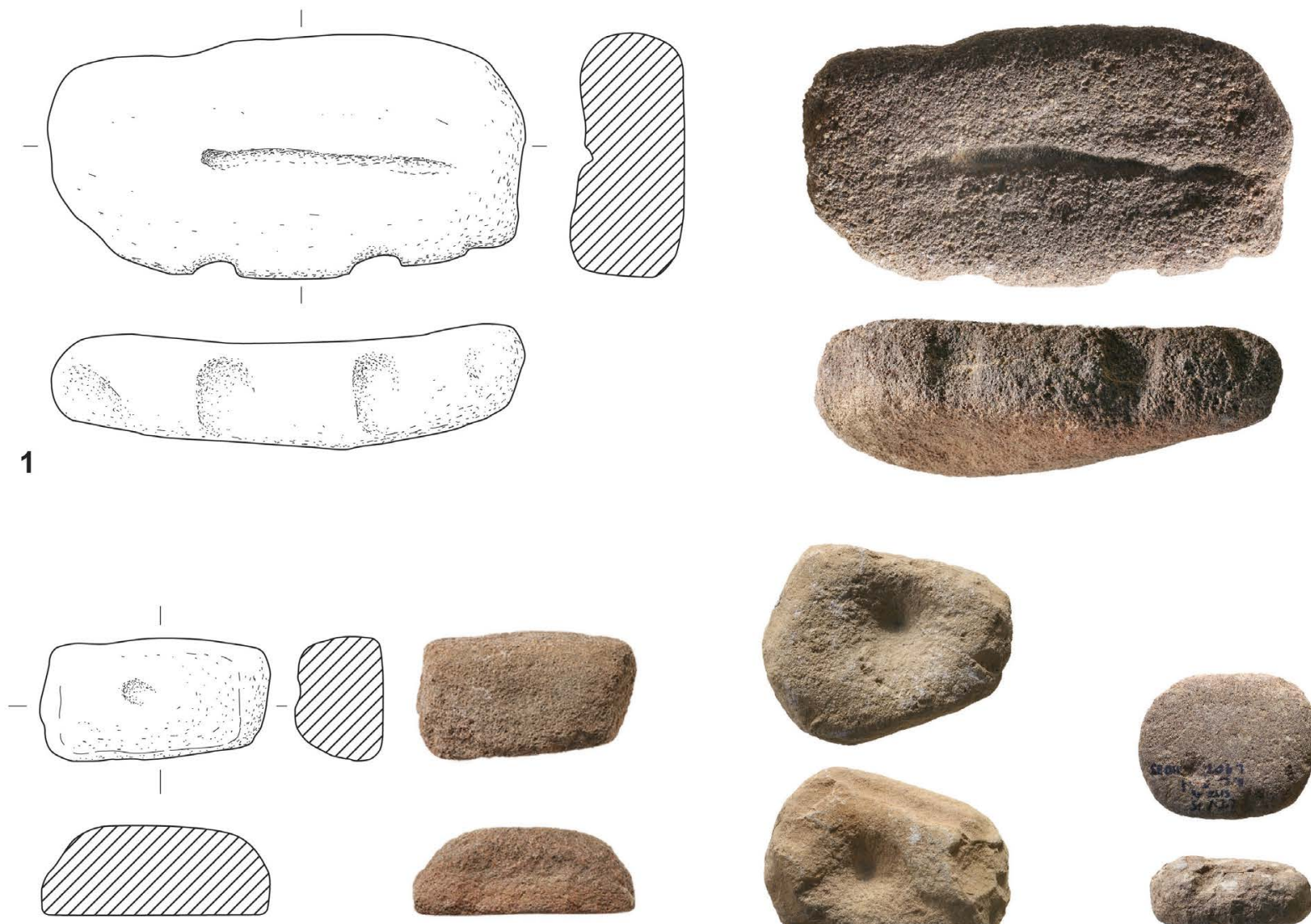

2
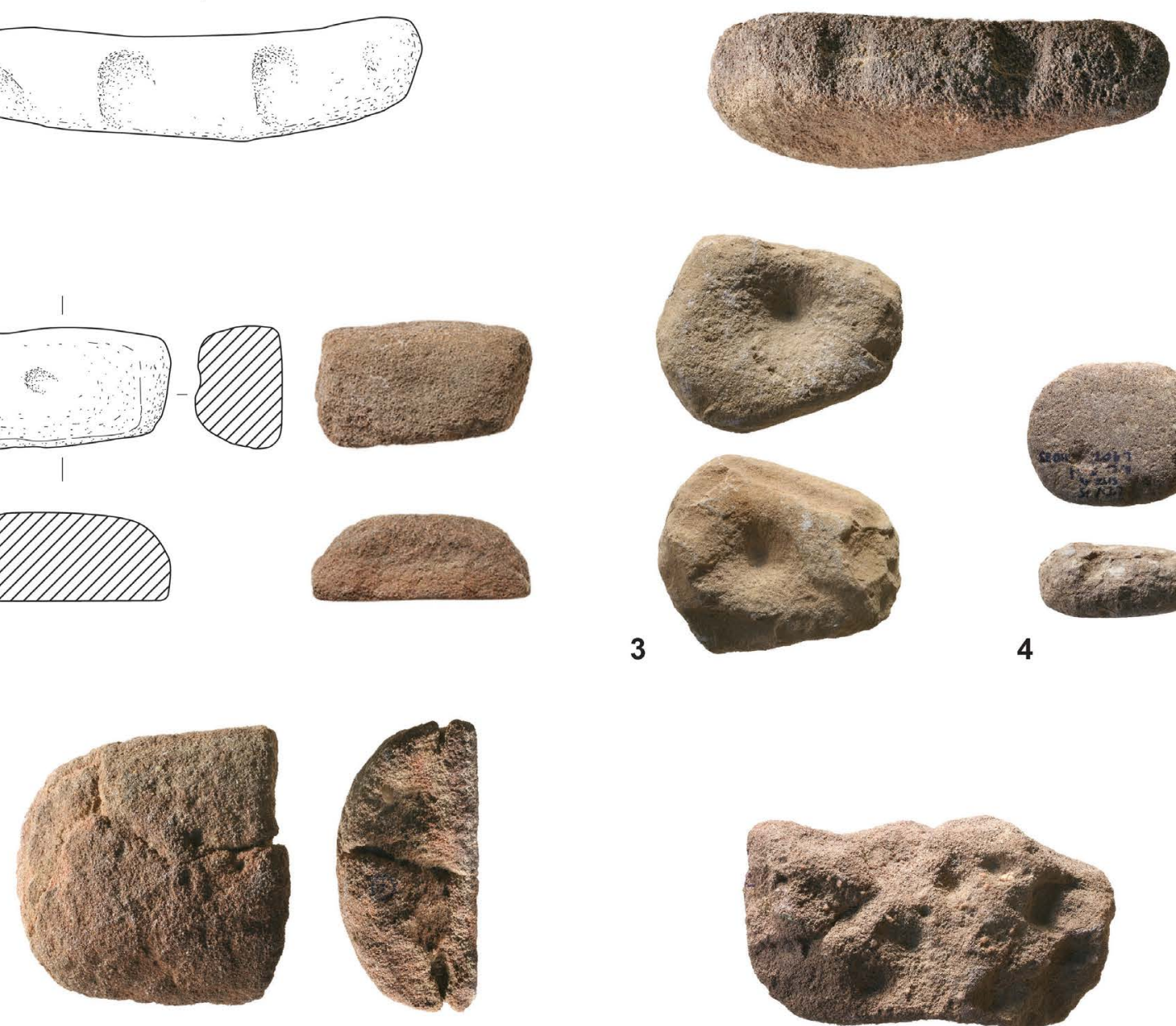

3
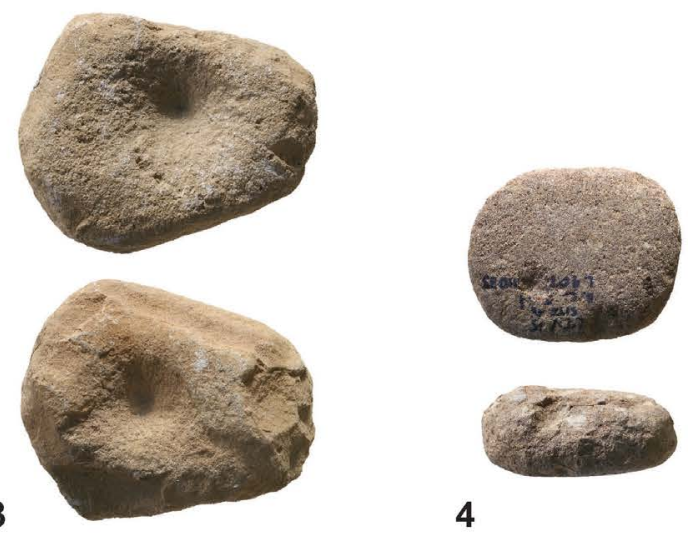

4
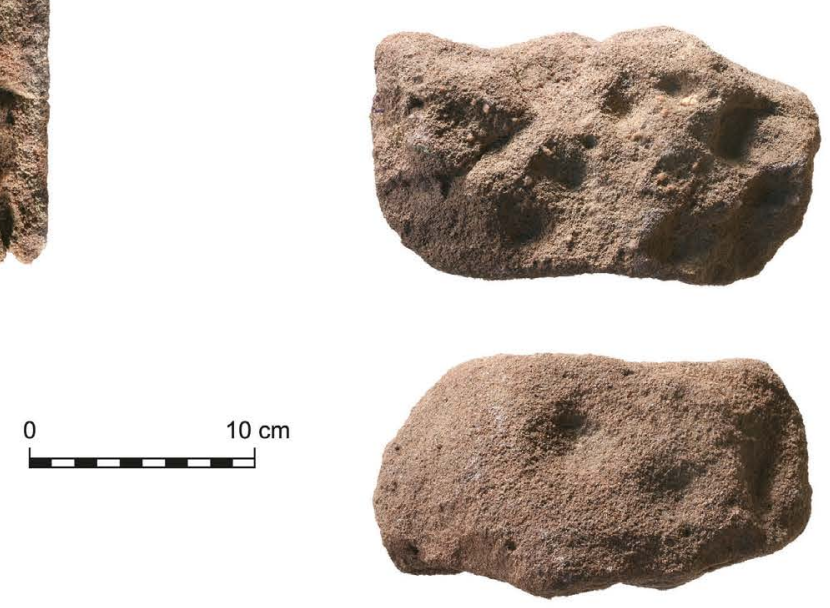

6

Figure 21. Various ground stone tools from Site 15. (1) B.6 (survey): lower (?) compacted coarse sandstone grinding stone with a groove and multiple dimples on sides and backside; (2) B.11003/2 (L.900, Area C): compacted sandstone rectangular polisher with a smooth surface; (3) B.7 (survey): limestone triangular pounder with dimples on both sides; (4) B.11033 (L.902, Area C): granite polisher; (5) B.4 (survey): lower "loaf shaped" grinding stone made of compacted coarse sandstone with dimples on the working surface; (6) B.14 (survey): irregular lower grinding stone made of compacted coarse sandstone, reused as an anvil. 


\section{Discussion}

Although most of the Timna ground stone tools do not differ significantly in form or size from those found at settlement sites (cf. Rosenberg 2008; Yahalom-Mack \& Panitz-Cohen 2009), we must reject the possibility that they were used primarily for food processing for the following reasons:.

The quantity of tools: The great quantity of ground stone tools which were scattered all over the surface at Site 34 is unparalleled at Iron Age settlement sites. This abundance is characteristic of other industrial copper production sites in antiquity.

The rock types: As opposed to the basalt and limestone rocks which were the preferred stones for the production of food processing tools from prehistory through to modern times (e.g., Hovers 1996: 181; Rosenberg 2008: 101; Yahalom-Mack \& Panitz-Cohen 2009; see also Rosenberg \& Golani 2012: 35), the coarse sandstone which was used at Timna for the manufacture the grinding implements erodes quickly under abrasion, and creates a great amount of rock dust.

The surface marks: The absence of striations and particularly surface polish on the Timna grinding stones indicates that they were not used for processing plant materials (e.g., Adams 2014). However, since grains have been found at Site 34, we cannot completely disregard the possibility that some of the food for the smelters was prepared on the top of the hill and not down in the valleys, where it is assumed the people lived in tents. Another possibility is that these grains were used for feeding the pack animals.

Element traces: A portable X-ray fluorescence examination conducted on one of the grinding slabs by Yuval Goren during the 2015 Field Season, demonstrated that its working surface had 6 times more copper than the other side - further supporting its connection to the copper production industry (See also Vardi et al. 2008: 14-17).

A limited and distinct repertoire: The Timna repertoire is more limited than the one found at settlement contexts, and lacks several tool types routinely found in contemporary settlement contexts, such as bowls and other vessels, polishing stones, stones used for cutting, and pestles, which have traditionally been associated with pounding hard foods, or as part of the cereal processing (Hovers 1996: 184). Furthermore, although there is not much quantitative data from contemporaneous settlement sites in the Levant, the data that is available (e.g., Rosenberg 2008: 101; Yahalom-Mack \& Panitz-Cohen 2009) supports the observation that the ratio of grinding stones to other crushing stones is different at Timna Site 34 than that which is associated with Iron Age food processing. At settlements sites, the grinding tools comprise over $60 \%$ of the ground stone tools, compared to $43 \%$ at Timna.

The great quantity, as well as typological and functional diversity, of ground stone tools discovered at Timna, suggest that a plethora of tasks necessitated their use as part of the chaîne opératoire of copper production. However, determining their function is difficult since the Iron Age copper smelting process is not fully understood, and ethnographic parallels for pre-industrial copper production are rare. The few studies which focused on ground stone tools at copper production sites (e.g., Vardi et al. 2008; Rosenberg \& Golani 2012; Webb 2015) deal with different periods and production scales, and thus have limited value for the study of the Timna ground stone assemblage. As opposed to the clear industrial context at Timna, these other studies were preoccupied with distinguishing between industrial and domestic ground stone tools (except Vardi et al. 2008, to some degree). In order to help us answer the question of what the different types of ground stone tools were used for, we collected several of the survey ground stone tools for continued research in the lab; we chose representative stones from different survey areas and recorded their location. The possible uses of the ground stone tools in the elaborate copper production process are discussed below. 


\subsection{Before the smelting: Ore beneficiation and preparation for smelting}

Simple crushing and sorting operations (beneficiation) of the copper ore were carried out within or close to the mines. The ore was then taken to the smelting sites, where more sophisticated sorting took place, using the ground stone tools, prior to smelting in the furnace (Craddock 1995: 156). Merkel (1990: 82), whose experiments are the most important references for understanding the copper smelting process and techniques at the period under discussion, wrote that during this careful laborious process of ore dressing as much gangue (lower grade mined material) as possible was removed in order to achieve a high level of metal content (see also Belgiorno et al. 2012: 28). Craddock (1995: 161) wrote of the importance of preparing a reasonably standard ore charge, both in composition and size, with as little variation as possible from one smelt to another.

To what size was the ore reduced during beneficiation and in preparation for smelting? Ethnographic information regarding the ideal size of copper ore is scarce, yet demonstrates the variety of practices even among the same groups of smelters. The ore sizes that are cited range from "small lumps" (Bisson 2000: 97) and the "size of a hen's egg” (Miller 1994: 80), to a cubic cm (Chaplin 1961: 56), pea-size (Craddock 1995: 161), and pulverized powder or dust which could be winnowed or freed of unwanted inferior elements (Herbert 1984: 52).

Tylecote \& Boydell (1978: 43, 49) produced copper by using ore which was reduced to a maximum size of $4 \mathrm{~mm}$. These small pieces were heavy enough to resist the up-draught in the furnace, and were more easily reduced to copper than the larger sizes of ore. Similarly, Merkel (1990: 106) wrote that the ore was ideally crushed into very small pieces (less than $5 \mathrm{~mm}$ ) before being placed within the furnace. Craddock (1995: 161) wrote that pea-sized ore particles were the optimum for smelting copper ore in the furnace, and described in detail how dimples and cup marks are created while crushing the ore (this is a general description, and does not apply to Timna in particular):

"The process of crushing the ore on a flat rock rapidly wears the surface into a small hollow. If the crushing was performed with small hand-held hammers then after the depression had reached a depth of about $10 \mathrm{~cm}$, it became inconvenient to use because of the danger of the fingers brushing the sides, and so the operation moved along a few centimetres. Thus a large flat rock surface could easily become covered with many small depressions. These should therefore be regarded as wear created by the crushing operations rather than mortars made deliberately for the crushing. However, sometimes very large mortars were cut into the rock for the purposes of crushing ore with large pestles..... The hammerstones generally wore in one of two quite characteristic patterns. Either they developed a rounded convex end or a very distinctive hollow dimple in the centres of their flat sides. The latter is normally interpreted as resulting from repeated impact with small hard nuggets of ore. Sometimes it is suggested that the hand action was to give a slight twist to the hammer at the moment of impact which could exacerbate this wear."

Others have also written about the use of pounders and anvils for crushing ore as part of the beneficiation process at smelting sites (e.g., Fendin 2006: 159; Webb 2015: 27; for ethnographic studies from Africa see Chaplin 1961: 56; Herbert 1984: 58-68). Although crushing the ore at Timna could have easily been done by pounding (see Figure 22), our tests have demonstrated that crushing the relatively soft sandstone ore used at Timna may have created over time the shallow mortars, but cannot create the small deep dimples and cup marks found on the granite pounders and anvils. These were created while pounding and crushing the hard slag (see below). In any case, Craddock (1995: 162) wrote that following the percussive crushing, some metal ores, such as gold and tin, were ground as fine as flour with rubbing action before the smelting. He assumed, however, that this was not the usual 
practice for copper ore, since a finely powdered ore would put out the fire. In any case, he mentioned a possible solution for this problem by agglomerating the mineral powders into cakes with animal dung before being charged to the furnace. Finally, a glance at many YouTube videos about experiments in traditional copper production demonstrates that it is indeed possible to use finely crushed ore (see, for example, Chapman \& Chapman 2012).

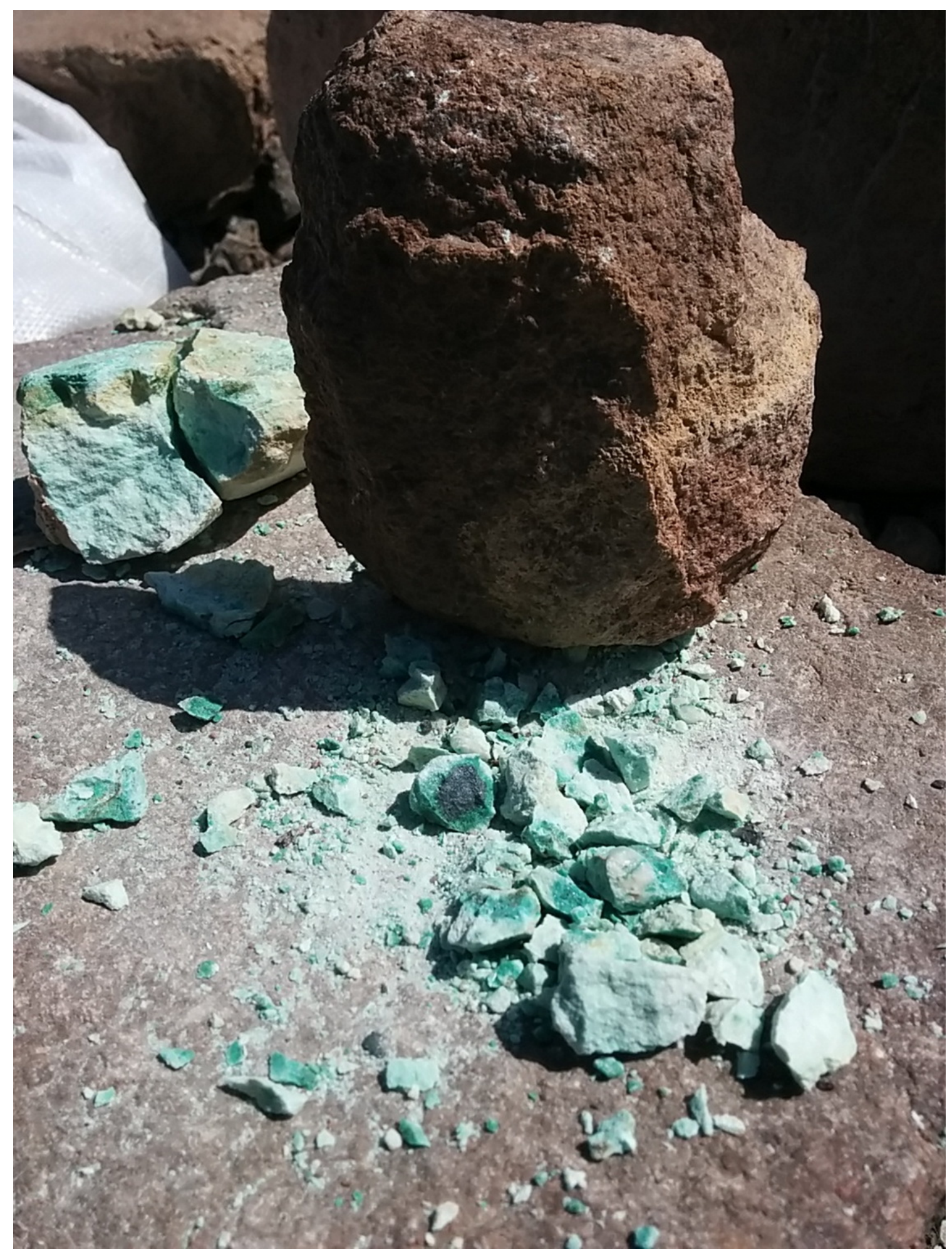

Figures 22. Modern experiments using ground stone tools which were collected from Site 34 - a granite pounder used to crush the local copper ore. 
Finally, Craddock (1995: 162) commented that, generally speaking, grinding stones were too soft to grind rock, and preferred to regard them as mills related to food production. However, as we have elaborated above, the grinding stones were not used to process food, and the compacted coarse sandstones were indeed strong enough to grind the ore that in Timna originated from relatively soft ore-bearing sandstone formations (Conrad \& Rothenberg 1980). The repertoire of ground stone tools from Site 34, particularly the huge quantity of grinding stones, hints at the fact that the copper ore was pulverized before being placed within the smelting furnaces. Indeed, the 2009 excavations of a slag mound at Site 30 revealed a cache of fine-crushed ore which was prepared for smelting (see Figure 23). Utilizing the grinding stones for this purpose would have given the smelters better control over the beneficiation process than using only the pounders. The copper ore sandstone would have been ground upon large static grinding slabs, or by using hand-held grinding stones (see Figure 24). This helped remove the excess sand and lower quality ore material, and prepared the ore for the smelting process within the furnace.

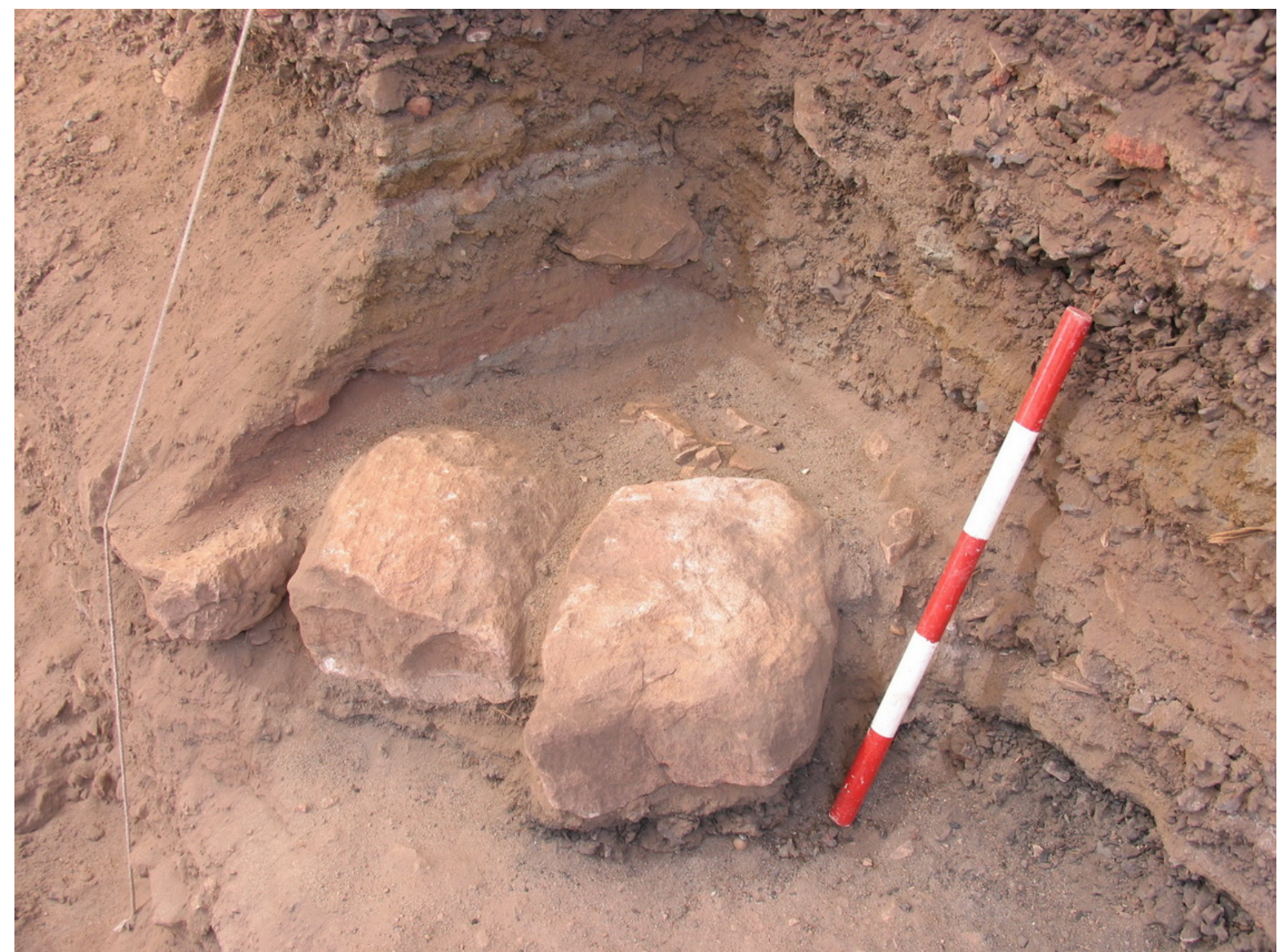

Figure 23. A rounded crushed-ore storage facility at Site 30 (Installation L.905). The green slag can be seen in the section (photo from Ben-Yosef et al. 2012: 54).

Many of the grinding stones, manufactured of the compacted coarse sandstone, have dimples and seem to have been used (or re-used) also for crushing or pounding. This may have been done as a secondary use after the grinding tools wore down or broke, or may have taken place simultaneously alongside the grinding. Since our experiments have demonstrated that the internal structure of the compacted coarse sandstones is not strong enough for continuous crushing or grinding of hard materials such as slag, these stones must have been used to crush the ore. 


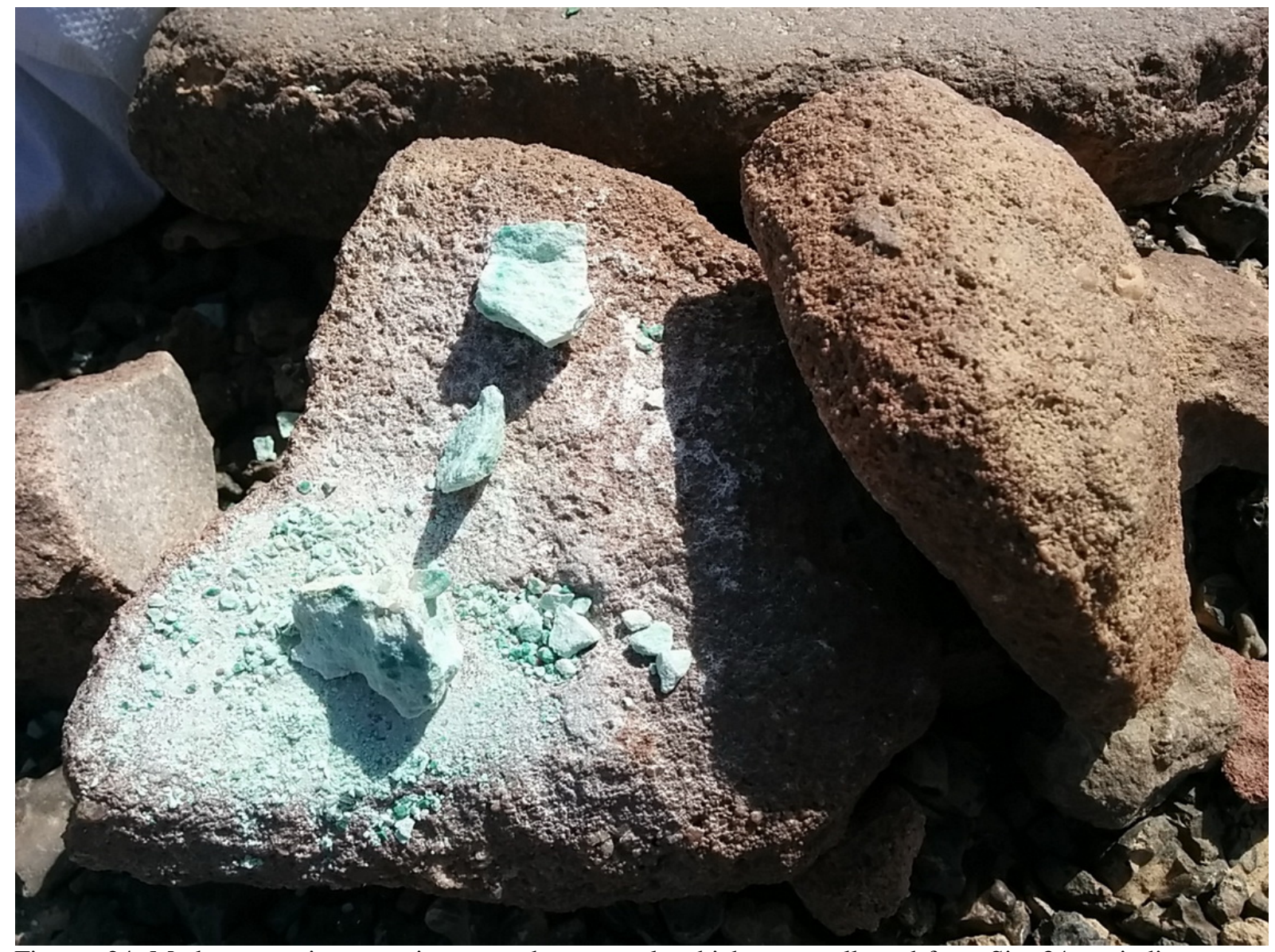

Figures 24. Modern experiments using ground stone tools which were collected from Site 34 - grinding stones used to grind the local copper ore.

The crushing and grinding of copper ore as described above may apply also to the preparation of flux, a different mineral that was added to the smelting mixture in order to reduce the smelting temperature and to lower slag viscosity. In Late Bronze and Iron Age Timna, it is assumed that iron ore (iron oxides, in particular hematite) was deliberately added in a ratio of 1:3 to the copper ore (Merkel 1990: 112), making flux preparation a significant part of the pre-smelting activities. Iron oxides are also found in the copper ore-bearing sandstone formations, suggesting the possibility of using self-fluxing copper ore, at least in earlier periods. If indeed iron oxides were deliberately added, these had to be crushed and probably ground in order to be mixed with the pulverized copper ore (see Figure 25).

\subsection{After the smelting: Slag crushing}

Copper was usually not separated completely from the slag during smelting. As a consequence, a systematic reworking of slag by crushing was necessary in order to extract entrapped prills of metal. Many of the pounders and stationary anvils were made of heavy granite rocks, which were strong enough to withstand continuous pounding and crushing of the rough slag in order to extract the small copper prills, which were then added to the copper extracted directly from the furnace (see Vardi et al. 2008: 18). The evidence points to a very careful recovery of copper from the slag (Hauptmann 2007: 246). Pounders were used for the same purpose at Ambelikou Alteri in Cyprus (Webb 2015: 23-24, 27), and at the Iron Age iron production area at Dan (Ilan 1999: 103). Anfinset (2000: 209) observed that in traditional Nepalese copper production, the copper itself was ground by a stone grinder into powder, which was then roasted and re-smelted in order to retrieve as pure a copper as possible. 


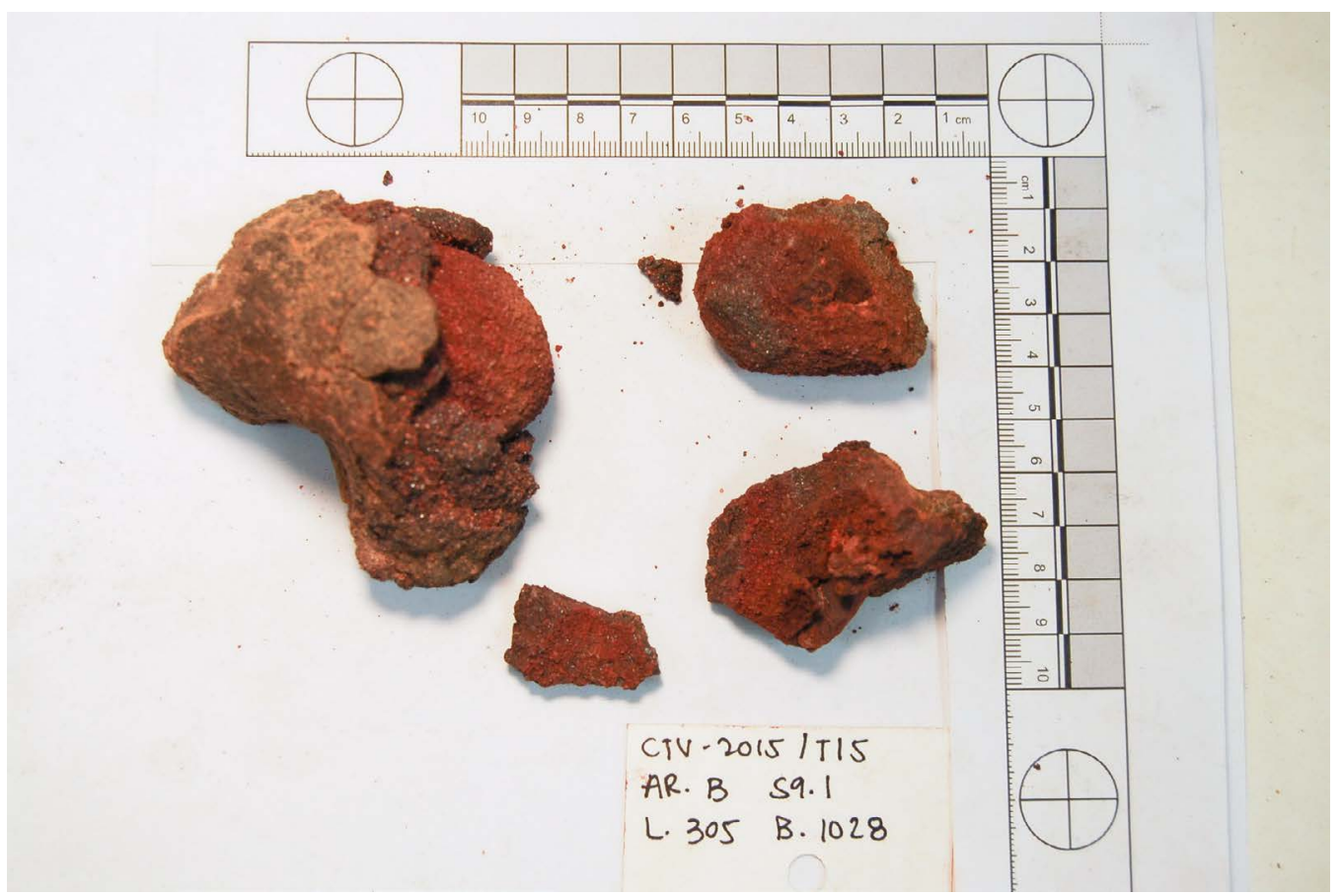

Figure 25. Iron oxides found at Site 15.

The result of this action is the slag fragments which form the slag mounds at the Timna smelting sites (see Figure 26). The pounding action created the dimples on the pounders, and the cup marks on the anvils (see Figure 27). Craddock (1995: 161) added that the hand-held stones with a highly polished dimple in the centre face were used with bow drills to make fire (e.g., Figure 9:1).

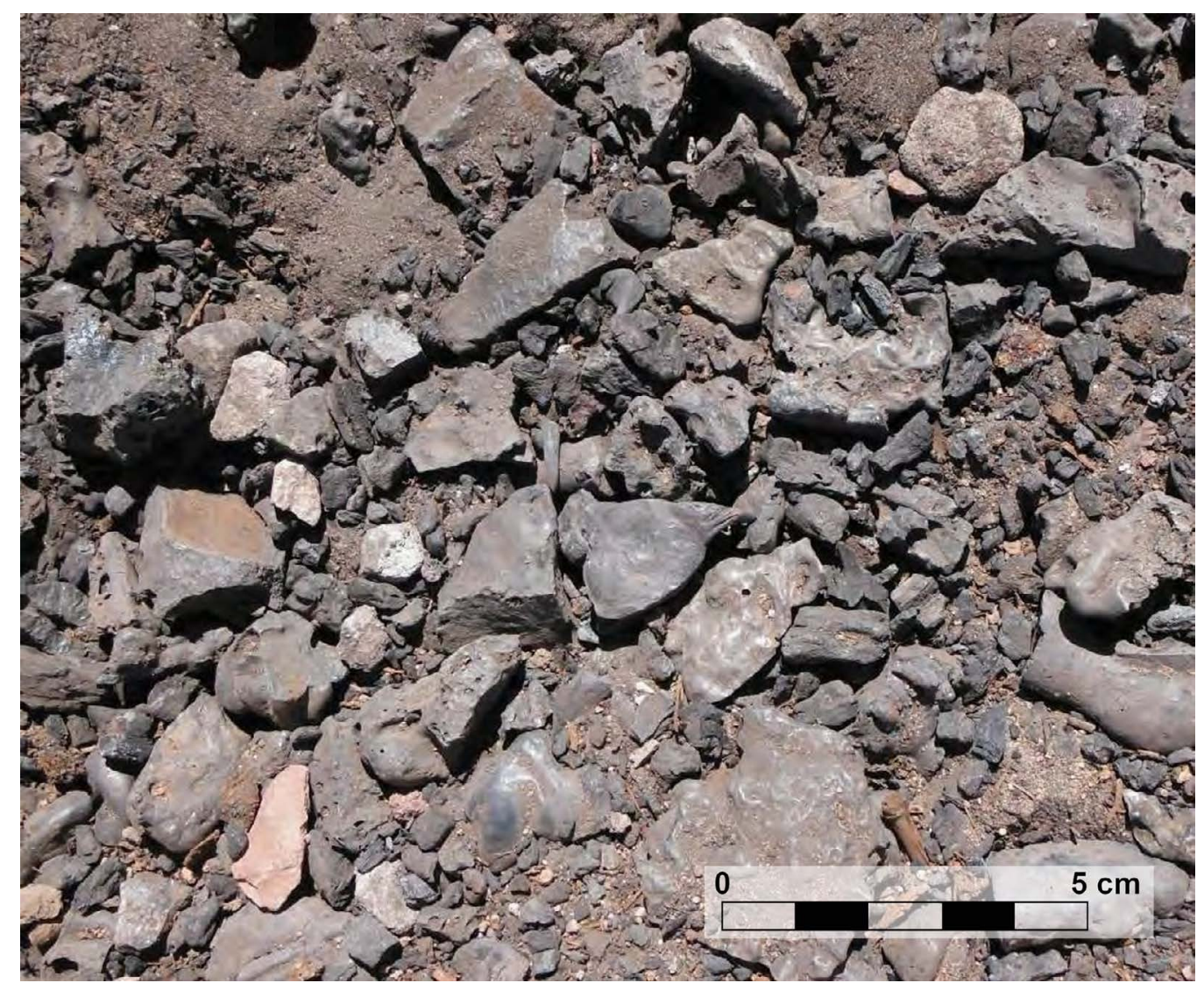

Figure 26. Crushed slag fragments from Site 34 


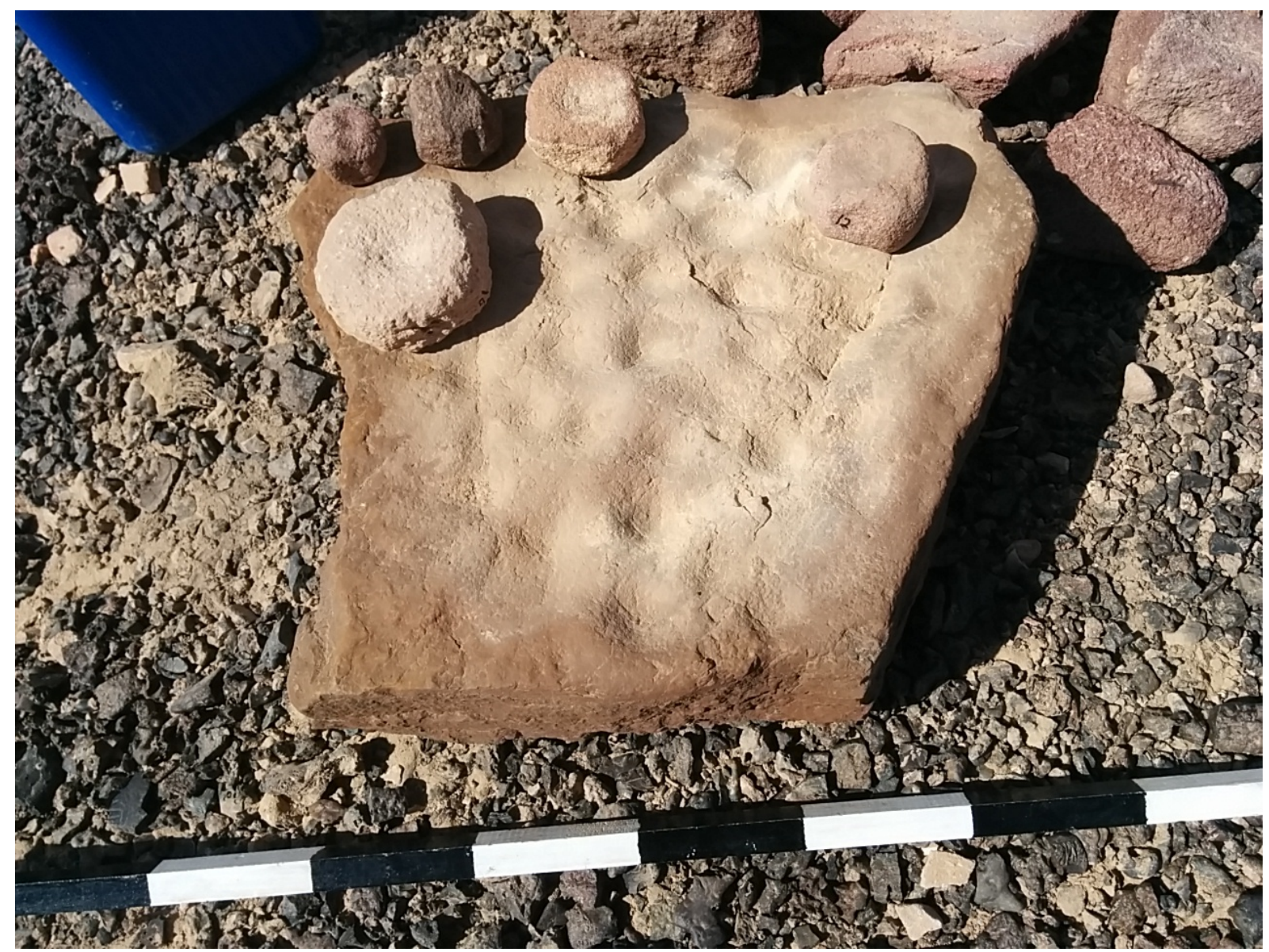

Figure 27. A modern reconstruction of the slag crushing method using ground stone tools which were collected from Site 34 surface survey (conducted in Feb. '15). The small dimpled pounders are situated on top of the anvil with multiple cup marks.

The finer crushing of some of the slags was done in larger granite or limestone boulder mortars or the ones cut into the bedrock. This crushing created fine slag fragments which were used as temper first and foremost for the construction of the furnaces themselves (BenYosef \& Levy 2014), and in the locally produced pottery vessels (Smith \& Levy 2008, Smith et al. 2014).

\section{Conclusions}

The varied geological landscape of Timna provided various types of rocks that are reflected in the ground stone assemblage. This assemblage represents an assortment of mostly red rock types carried up the hill to Site 34 from nearby locations within the Timna Valley. The local fragile sandstone that makes up Site 34 was hardly utilized for the copper smelting industry. The smelters, who were probably highly esteemed professional artisans (Sapir-Hen \& Ben-Yosef 2014), were familiar with different raw material properties and the requirements dictated by the tool purposes; the entire assemblage suggests that much effort was expended on the raw material procurement, and artefact manufacture and maintenance.

The lack of detailed relevant ethnographic documentation makes it difficult to understand the exact functions of the specific tool types. Nevertheless, the richness of ground stone data from the Timna Iron Age copper smelting sites, along with tight control over the context of the finds, has allowed us to offer an explanation of how the ground stone tools were used during the various stages of copper production in the early Iron Age, and to present the basic toolkit of ancient metal smelters: 
- The final stages of ore beneficiation were done within the smelting camps themselves at a distance of $2-3 \mathrm{~km}$ from the mines. This process involved crushing and grinding the mined rocks in order to separate the high quality ore from other parts of the sandstone. The use of pounders, grinding stones and mortars was ideal for this purpose. As the mines themselves are scattered over extensive areas along the circumference of the Timna Valley, it was much more efficient to concentrate final beneficiation efforts in one central location, where relevant tools and skilled workers could focus on this work in proximity to the smelters.

- Our study indicates that the final product of the beneficiation stage was powder, rather than chunks or fragments of ore and flux. The pulverized high quality copper ore, possibly mixed with flux of pulverized iron oxides, was placed in the furnaces.

- After the smelting, slag which is found at the site in various sizes was crushed between the pounders and the anvils and mortars in order to extract copper prills.

- Some of the slags were further crushed and ground within the mortars, including those cut into the bedrock, into fine material which could be used as temper in pottery and smelting installations.

- Some of the ground stone tools were probably used for manufacturing and fixing other tools.

The ground stone assemblage at Site 34 and its physical condition demonstrate beyond any doubt that indeed this area was used primarily for copper smelting and other, domestic activities were scarce or completely absent. In fact, the scale of copper working is reflected in the great amount of stone tools used for that purpose. This observation is also supported by the study of the pottery assemblage from Site 34, which is primarily comprised of serving vessels and almost no storage vessels and cooking pots. The assemblage is characterized by an emphasis on crushing and grinding, and demonstrates heavy wear and fracture patterns. Another diagnostic aspect of the industrial assemblage is the intensive reuse of broken or worn out grinding tools for heavy pounding and crushing, giving the impression of expedient use of whatever heavy stones suited to the working of hard substances were at hand. Alternatively, these stones may have been used simultaneously for both grinding and pounding. Webb (2015: 24) noted such patterns of use and damage at the metallurgical site of Ambelikou Aletri in Cyprus, and stresses that this is atypical of the breakage patterns in the domestic assemblages.

Although by no means exhaustive, this discussion presents a first attempt to understand the functions of these tools in a Levantine Iron Age primary metal production context. Our future plans are to conduct a comparison of the stone assemblages' characteristics between Timna and Wadi Faynan (see Levy et al. 2016). This particular period represents a culmination of technological evolution of copper production, which was probably orchestrated by a strong centralized entity (e.g., Ben-Yosef et al. 2012). One should therefore take caution when utilizing these results to study other metallurgic industries with different geological settings, from different periods, and of different capacities.

\section{Acknowledgments}

The artefacts were photographed by P. Shrago and drawn by N. Cohen and Y. Gottlieb of the Sonia and Marko Nadler Institute of Archaeology of Tel Aviv University. O. Yagel and V. Workman supervised the Site 34 Survey, and C. Smitheram supervised the Site 15 survey. We would also like to thank the following people for their assistance and advice in the field and while studying the finds: Y. Weingarten, M. Beyth of the Geological Survey of Israel, Y. Rowan and J. Ebeling. Finally, we would like to thank D. Rosenberg and the anonymous reviewers for their helpful comments. The study of the Timna ground stones was made possible through A. Greener's Educational and Cultural Affairs (ECA) and Ernest S. Frerichs 
Fellowships at the W.F. Albright Institute of Archaeological Research. The CTV Project is supported by the Yad Hanadiv Foundation and the Marie Curie FP7-PEOPLE-2012-CIG grant \#334274. Photo 3 is courtesy of U. Avner, photo 6 by Y. Weingarten, photo 25 is by M. Cavanagh and Photo 26 is by W. Ondricek). We thank them all.

\section{References}

Adams, J.L. 2014, Ground Stone Analysis: A Technological Approach. The University of Utah Press, Salt Lake City, 318 p.

Anfinset, N. 2000, Copper technology in contemporary Western Nepal. A discussion of its form, function and context. In: Form, Function and Context. Material Culture Studies in Scandinavian Archaeology (Olausson, D., \& Vandkilde, H., Eds.), Acta Archaeologica Lundensia, Series in 8, 31. Wallin \& Dalholm Boktryckeri AB, Lund: p. 203-212.

Belgiorno, M.R., Ferro, D., \& Loepp, D.R. 2012, Pyrgos-Mavrorachi in Cypriot metallurgy. In: Eastern Metallurgy and Metalwork in the Second Millennium BC. A Conference in Honour of James D. Muhly Nicosia, 10th-11th October 2009 (Kassianidou, V., \& Papasavvas, G., Eds.), Oxbow Books, Oxford: p. 26-34.

Ben-Yosef, E. 2010, Technology and Social Process: Oscillations in Iron Age Copper Production and Power in Southern Jordan. PhD Dissertation at the Department of Anthropology, University of California at San Diego, San Diego, 1124 p.

Ben-Yosef, E. in press. The Central Timna Valley Project: Research Design and Preliminary Results. In: Mining for Copper: Essays in Memory of Professor Beno Rothenberg (BenYosef, E., Ed.), The Tel Aviv University Institute of Archaeology, Tel Aviv.15 p.

Ben-Yosef, E., \& Levy, T.E. 2014, The material culture of Iron Age copper production in Faynan. In: New Insights into the Iron Age Archaeology of Edom, Southern Jordan: Surveys, Excavations, and Research from the University of California, San Diego Department of Antiquities of Jordan, Edom Lowlands Regional Archaeology Program (ELRAP) (Levy, T.E., Najjar, M., \& Ben-Yosef, E., Eds.), Cotsen Institute of Archaeology, UCLA, Los Angeles: p. 887-959.

Ben-Yosef, E., Shaar, R., Tauxe, L., \& Ron, H. 2012, A new chronological framework for Iron Age copper production at Timna (Israel). Bulletin of the American Schools of Oriental Research, 367: 31-71. doi:10.5615/bullamerschoorie.367.0031

Beyth, M., Segev, A., \& Bartov, Y. 1999, Be’er Ora Geological Map, Israel Geological Survey, Jerusalem.

Bisson, M.S. 2000, Precolonial copper metallurgy: Sociopolitical context. In: Ancient African Metallurgy: The Socio-Cultural Context (Bisson, M.S., Childs, S.T., De Barros, P., \& Holl, A.F.C., Eds.), Altamira Press, Walnut Creek: p. 83-146.

Chaplin, J.H. 1961, Notes on traditional smelting in Northern Rhodesia. South African Archaeological Bulletin, 16(62): 53-60. doi:10.2307/3886869

Chapman, D.A. \& Chapman, S.G., (directors) 2012, Prehistoric copper smelting in a pit! Produced by Ancient Arts. YouTube. Running time: 5m, 43s.

URL: https://youtu.be/8uHc4Hirexc

Conrad, H. G., \& Rothenberg, B. 1980, Antikes Kupfer im Timna-Tal. Der Anschnitt Beiheft. Deutsches Bergbau-Museum, Bochum, 236 p. 
Craddock, P.T. 1995, Early Metal Mining and Production, Smithsonian Institution Press, Washington D.C., 363 p.

Fendin, T. 2006, Grinding processes and reproductive metaphors. In: Old Norse Religion in Long-term Perspectives: Origins, Changes, and Interactions. An International Conference in Lund, Sweden, June 3-7, 2004 (Andrén, A., Jennbert, K., \& Raudvere, C., Eds.), Nordic Academic Press, Lund: p. 159-163.

Hauptmann, A. 2007, The archaeo-metallurgy of copper. Evidence from Faynan, Jordan. Springer, Berlin, 388 p.

Herbert, E.W. 1984, Red Gold of Africa: Copper in Precolonial History and Culture. The University of Wisconsin Press, Madison, 413 p.

Hovers, E. 1996, The groundstone industry. In: Excavations at the City of David 1978-1985: Vol. IV. Various Reports (Ariel, D., \& De Groot, A., Eds.), Qedem 35, Hebrew University Institute of Archaeology, Jerusalem: p. 171-203.

Ilan, D. 1999, Northeastern Israel in the Iron Age I: Cultural, Socioeconomic and Political Perspectives. PhD Dissertation at Tel Aviv University, Tel Aviv, 1124 p.

Levy, T.E., Bettilyon, M. \& Burton, M.M. 2016. The Iron Age copper industrial complex: A preliminary study of the role of ground stone tools at Khirbat en-Nahas, Jordan. Journal of Lithic Studies, 3(3): 313-335 p. doi:10.2218/jls.v3i3.1648

Levy, T.E., Najjar, M., \& Ben-Yosef, E. 2014, New Insights into the Iron Age Archaeology of Edom, Southern Jordan: Surveys, Excavations, and Research from the University of California, San Diego - Department of Antiquities of Jordan, Edom Lowlands Regional Archaeology Program (ELRAP) (Vols. I-II). Cotsen Institute of Archaeology Press, University of California, Los Angeles, 1034 p.

Merkel, J. F. 1990, Experimental reconstruction of Bronze Age copper smelting based on archaeological evidence from Timna. In: The Ancient Metallurgy of Copper: Archaeology, Experiment, Theory (Rothenberg, B., Ed.), Researches in the Arabah 1959-1984, Vol. 2. Institute for Archaeo-Metallurgical Studies [and] Institute of Archaeology, University College London, London: p. 78-122.

Miller, D.E. 1994, Kaonde copper smelting: Technical versatility and the ethnographic record. In: Society, Culture and Technology in Africa (Childs, S.T., Ed.), MASCA Research Papers I: Science and Archaeology, Vol. 11 Supplement. University of Pennsylvania, University Museum, Philadelphia: p. 79-85.

Pigott, V. 1996, Near Eastern archaeometallurgy: Modern research and future directions. In: The Study of the Ancient Near East in the 21st Century (Cooper, J.S. \& Schwartz, G.M., Eds.), Eisenbrauns, Winona Lake, Indiana: p. 139-176.

Rosenberg, D. 2008, Spatial distribution of food processing activities at Late Iron I Megiddo. Tel Aviv, 35: 96-113. doi:10.1179/tav.2008.2008.1.96

Rosenberg, D., \& Golani, A. 2012, Groundstone tools of a copper-smiths’ community: Understanding stone- related aspects of the Early Bronze Age site of Ashqelon Barnea. Journal of Mediterranean Archaeology, 25(1): 27-51. doi:10.1558/jmea.v25i1.27

Rothenberg, B. 1990, The Ancient Metallurgy of Copper: Archaeology, Experiment, Theory. Researches in the Arabah 1959-1984, Vol. 2. Institute for Archaeo-Metallurgical Studies [and] Institute of Archaeology, University College London, London, 191 p. 
Rothenberg, B. 1999, Archaeo-metallurgical researches in the Southern Arabah 1959-1990. Part 2: Egyptian New Kingdom (Ramesside) to Early Islam. Palestine Exploration Quarterly, 131: 149-175. doi:10.1179/peq.1999.131.2.149

Rowan, Y.M., \& Ebeling, J.R. 2008, Introduction: the potential of ground stone studies. In: New Approaches to Old Stones: Recent Studies of Ground Stone Artifacts, (Rowan, Y.M., \& Ebeling, J.R., Eds.), Equinox, London, 378 p.

Sapir-Hen, L., \& Ben-Yosef, E. 2014, The socioeconomic status of Iron Age metalworkers: animal economy in the "Slaves' hill”, Timna, Israel. Antiquity, 88(341): 775-790. doi:10.1017/S0003598X00050687

Smith, N.G., \& Levy, T.E. 2008, The Iron Age pottery from Khirbat en-Nahas, Jordan: A preliminary study. Bulletin of the American School of Oriental Research, 352: 41-91. URL: http://www.jstor.org/stable/25609301

Smith, N.G., Levy, T.E., \& Goren, Y. 2014, From lowland to highland - petrographic perspectives on Iron Age Edom. In: New Insights into the Iron Age Archaeology of Edom, Southern Jordan: Surveys, Excavations, and Research from the University of California, San Diego - Department of Antiquities of Jordan, Edom Lowlands Regional Archaeology Program (ELRAP) (Levy, T.E., Najjar, M., \& Ben-Yosef, E., Eds.), Cotsen Institute of Archaeology, UCLA, Los Angeles: p. 461-491.

Tylecote, R.F., \& Boydell, P.J. 1978, Experiments on copper smelting based on early furnaces found at Timna. In: Chalcolithic Copper Smelting: Excavations and Experiments (Rothenberg, B., Ed.) Archaeo-Metallurgy IAMS monograph no. 1. Institute for Archaeo-Metallurgical Studies, London, p. 27-49.

Vardi, J., Shilstein, S., Shalev, S., \& Yekutieli, Y. 2008, The Early Bronze Age IV chipped and ground stone assemblage of 'En Yahav and its relation to copper smelting activities. Journal of the Prehistoric Society, 38: 1-20.

URL: http://www.jstor.org/stable/23386445

Webb, J.M. 2015, Identifying stone tools used in mining, smelting, and casting in Middle Bronze Age Cyprus. Journal of Field Archaeology, 40: 22-36. doi:10.1179/0093469014Z.000000000108

Wright, K. I. 1992, A Classification system for ground stone tools from prehistoric Levant. Paléorient, 18(2): 53-81. doi:10.3406/paleo.1992.4573

Yahalom-Mack, N., \& Panitz-Cohen, N. 2009, Groundstone implements. In: Excavations at Tel Beth-Shean 1989-1996, Volume III: The 13th-11th Century BCE Strata in Areas N and S (Panitz-Cohen, N., \& Mazar, A., Eds.), The Israel Exploration Society (and) The Institute of Archaeology, The Hebrew University of Jerusalem, Jerusalem: p. 719-736. 